Portland State University

PDXScholar

5-1-1968

\title{
In-service education for teachers of family life education from a sociological viewpoint
}

Helen M. Running

Portland State University

Follow this and additional works at: https://pdxscholar.library.pdx.edu/open_access_etds Let us know how access to this document benefits you.

\section{Recommended Citation}

Running, Helen M., "In-service education for teachers of family life education from a sociological viewpoint" (1968). Dissertations and Theses. Paper 9.

https://doi.org/10.15760/etd.9

This Thesis is brought to you for free and open access. It has been accepted for inclusion in Dissertations and Theses by an authorized administrator of PDXScholar. Please contact us if we can make this document more accessible: pdxscholar@pdx.edu. 
AN ABSTRACT OF THE THESIS OF

Helen M. Running for the MST in Sociology

Date thesis is presented Mayg/5, 1968

Title: IN-SERVICE EDUCATION FOR TEACHERS

OF FAMILY LIFE EDUCATION FROM A SOCIOLOGICAL VIEWPOINT

Abstract approved

Harmony is found between a specific area of professional famfly life Iiterature and the results of several surveys from within a particular metropolitan area. Revealed is a teacher inadequacy to the task of family life education in the primary and secondary schools. Deterrents are found to be a lack of both pertinent knowledge and skill.

Having shown consensus that the stated problem exists the further purpose of the thesis is to propose an aid to its remedy. Three factors require attention. Teachers need additional information from both the social and physical sciences. They need an opportunity to become aware of inhibiting attitudes. Lastly, teachers need experience in creating a dialogue-centered classroom. An in-service teacher education program in fanily life education is proposed to modify deterrents to teacher adequacy.

The proposed program stresses the application of sociological concepts to the mode of conducting the sessions as well as to its content. The resulting kind of education program provides an environment which both stimulates and nurtures readiness for learning.

Conmunication is found to be basic to human interaction and therefore also to human development. It is through the communicative process that teachers-in-service are assisted in becoming aware of their 
relevant attitudes. At the same time, communicative skills are developed. Concurrently an analytic frame of reference is encouraged through the suggested materials and their use. Care is given in selecting a wide range of types of materials representing contrasting soctal psychological views.

Recognizing the difficulty of maintaining objectivity while discussing potentially emotion laden topics a soctological tool is suggested. Purpose of the tool is to both assist in analysis of materials and to encourage objectivity.

Following an accounting of purposes and goals of the in-service program, techniques are given for its implementation. The program itself consists of ten sessions. Each session has a separate topic accompanied by suggested materials. Topics are chosen in order to first lead the teacher-1n-service toward an analytical approach to family life materlals. Further, teachers are encouraged to seek out frames of reference used in writings on human development. Through discussion teachers will become an active part of the material under study. Several of the sessions are concerned with pertinent aspects of the social institutions of family, religion, education and economics. In addition extensive consideration of physical aspects of human development and their social implications is given. Soclal change as it is related to the family and male and female roles is important. This emphasis is entirely in keeping with the social psychological frame of reference in which the entire study is placed.

Through Implementation of the described in-service program the deterrents to teacher adequacy to the family life education task may be modified. 
IN-SERVICE EDUCATION FOR TEACHERS OF

FAMILY LIFE EDUCATION FROM A SOCIOLOGICAL VIEWPOINT

by

HELEN M. RUNNING

\author{
A THESIS \\ submitted to \\ PORTLAND STATE COLLEGE
}

In partial fulfillment of

the requirements for the

degree of

MASTER OF SCIENCE OF TEACHING SOCIOLOGY

\title{
PORTLAND STATE COLLEGE
}

LIBRARY 
APPROVED:
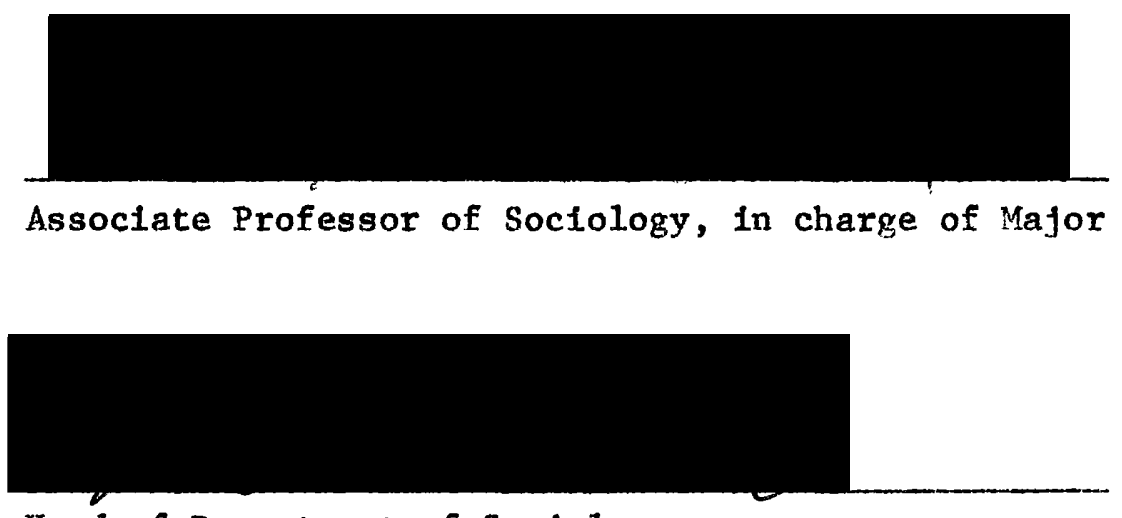

Head of Department of Sociology

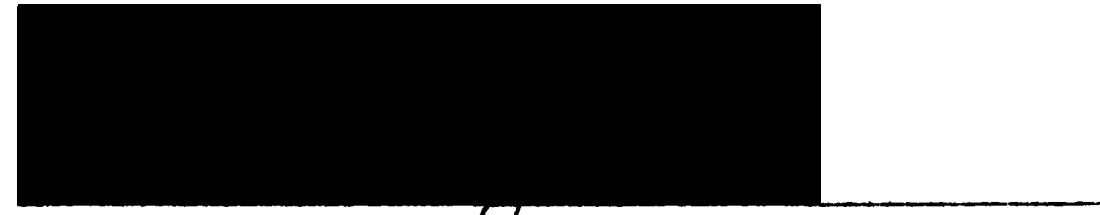

Dean of Graduate studiles

Date thesis is presented: May 15, 1968

Typed by: City Center Business Service 
ACKNOWLEDGMENT

This thesis could not have

been prepared without the constant

encouragement of my advisor

Dr. Earle H. MacCannell 
I. Introduction ....................... 1

The Problem ..................... . 1

Defining Family Life Education ............. 2

Purpose of the Study . . . . . . . . . . . . . . 4

II. Research into the Conditions Surrounding the Stated Pedagogical

Problem as Found in a Metropolitan Area . . . . . . . . 7

Some Present Conditions Researched . . . . . . . . 8

Some Recent Organized Efforts to Change Existing Conditions - 17

General Conditions Surrounding Family Life Education as

Viewed by Current Literature of that Field . . . . . . . . 21

Summary of Conditions Researched . . . . . . . . . 23

III. How Can the Deterrents to Teaching both the Blological and the

Soclological Aspects of Family Life in Primary and

Secondary Schools be Modified? . . . . . . . . . . . 24

IV. An In-Service Education Program for Teachers of Family Life

Education from a Sociological V1ewpoint . . . . . . . . . 27

What Kind of Education for Fanily Life? . . . . . . . . 27

Communication Theory and Fanily Life Education . . . . . 29

Communication and Psychology Relating to Family Life Education Materials .. . . . . . . . . . . 31

Contrasting Psychologies Attached to Sociological

Perspectives Found in Fanily Life Materials . . . . . . 34

Purposes and Goals of this Proposed In-Service Education Program ... . . . . . . . . . . . . . 43

Suggested Teaching Techniques Relevant to the Program Outline ................. . . 44 
Introduction and Program Outline . . . . . . . . . 49

Conclusion to the In-Service Program . . . . . . . 73

V. Thesis Summary and Conclusions . . . . . . . . . 76

Bibllography ..................... 79

Append1x A . . . . . . . . . . . . . . . . 81

Appendix B . . . . . . . . . . . . . . . 83

Appendix C . . . . . . . . . . . . . . 86

Appendix D . . . . . . . . . . . . . . . . . . 89

Append1x E . . . . . . . . . . . . . . . . . 91

Appendix F . . . . . . . . . . . . . . . 94

Footnotes . . . . . . . . . . . . . . . . 97 
I Portland Teachers' Questions Addressed to Dr. Mary Calderone Following Her Lecture on "Sexuality" . . . . . . . . 9

II Parents' Questions Addressed to Dr. Mary Calderone following Her Lecture on "Sexuality" . . . . . . . . . . 10

III Male Technical High School Students' Questions to Dr. Mary Calderone following Her Lecture on "Sexuality" . . . . . 11

IV Parents' Response to Film Vlewing . . . . . . . . . 12

V Student Attitude Survey . . . . . . . . . . . . 13

VI Federal Maternal Care Clinic Patients . . . . . . . 15 
IN-SERVICE EDUCATION FOR TEACHERS OF

FAMILY LIFE EDUCATION FROM A SOCIOLOGICAL VIEWPOINT

$I$

INTRODUCTION

THE PROBLEM

Famtiy 1tfe education whtch would increase prtmary and secondary student awareness of potentlals and posstbilities in that area, poses the pedagogical problem of how to remedy teacher inadequacy for the task. Many teachers are interested in teaching famfly 11fe. Howèver, fam1ly life education has both blological and soclological aspects. For example, human sexualfty, an important factor in faintly iffe education, is a composite of social process and physical function. This means a we11 prepared Eamily life educator should be knowledgeable In applicable parts of both the soclal and physical sciences. In addition, a fanfly life teacher must be able to communicate comfortably in both areas. Few teachers profess the required knowledge and skill. The pedagogical problem of remedying their Inadequacy denands the attention of those concerned with teacher preparation. 
DEFINING FAMILY LIFE EDUCATION

Before explaining the purpose of this paper in relation to the problem of remedying teacher inadequacy in the famlly life area, definitions of family life education should be considered. Consensus on a definition of family life education is yet to be reached. This is to be seen at the highest professional level. A study which began in 1963 Involved a nation-wide sampling of 66 respondents. 1 They were described as being in the top echelon of professional leadership in the family Iffe fleld.

Respondents were asked, In part, to evaluate the following "working definltion" of family life education:

"Family 1ife education Involves any and all school experiences deliberately and consciously used by teachers in helping to develop the personalities of students to their fullest capacities as present and future family menbers -- those capacities which equip the Individual to solve most constructively the problems unique to his family role."

of the 66 respondents, 23 are in higher education, 20 represent communtty agencles and 23 are employed by public schools. None of the public school people rejected the definition. But $30.4 \%$ of the higher education and $20.0 \%$ of the community agency representatives were unwilling to accept it. Those who refected the definttion found its breadth most offensive. E. Z. Dager, Associate Professor of Soclology, Purdue University, sald the field of family life education needs delimitation. He would retain only the interpersonal aspects. Care in using a social-psychological frame of reference for personality was asked by Richard Kerckoff, Washington (D.C.) School of Psychiatry. He would like emphasis of potentlals, rather than only 
problems. Harold T. Christensen, Professor of Soc1ology, Purdue University, and David Mace, Executive Director, American Assoclation of Marriage Counselors, asked for attention to both Eunctional and academfc consideration of family 11fe. Reuben Hill, Professor of Soctology, Director of Minnesota Family Study Center, University of Minnesota, and Lester A. Kirkenda11, Professor of Family Life, Oregon State University, called the definition too general and vague.

In their written comments a highly significant number of the family life experts held to a working definttion of famlly life centering on interpersonal relationships. Though nost favored the fncluston of sex education, $10.9 \%$ would de-emphastze 1t. There was no clarification as to whether those who would de-emphasize sex education also favored the Interpersonal approach, nor if the reverse were true.

In May of 1967 the "Teacher Exchange For High Schools and Colleges," a department of the Joumal of Marriage and the Family, edited by Rose M. Somerville, City University of New York, discussed "The Relationship Between Fanily Life Education and Sex Education." A symposium of fantly life education specialists considered the topic. The editor came to the conclusion that "...famlly life education is broader than sex education and can include the latter in most education programs."

Contributing editor, T. Joel. Moss, Brigham Young University, took. strongest exception to the conclusion. On a religlous basis he is deeply concerned that "...sex education always be taught in a value context." He holds reservations about including sex education in fanily 11fe programs unless the value context can be assured. 
It has already been stated that this paper is addressed to a pedagogical problem. It should be very clear that our working definition of family life education refers to intentional educational endeavors. This paper examines these endeavors in a sociological frame of reference. Therefore, the resulting definition of family life education takes an interactional approach which does not Ignore the blological aspects of human sexuality.

For this paper then, a working definition of family life education is "classroom education dealing with both the biological and sociological aspects of the individual's development which particularly involve awareness of one's present and potential family interaction and its relationshlp to patterns of the ongoing life process."

The above definition clearly considers sex education to be a part of family life education. Furthermore, the intent is to avoid a "problematic" or even an "adjustive" approach. Instead, stress is placed upon human interaction as an ongoing process. Lastly, the definition places the study within the confines of the classroom. These guidelines are set while fully accepting the broader concept of family Iife education as a phenomenon beginning at birth. That is, learning begins at birth. Initially, learning is through the individual's experience within the family setting. The school begins its contribution to the learning process only after the home has laid its foundation.

\section{PURPOSE OF THE STUDY}

Now that a working defintition of family life education for this 
paper has been established, the purpose of the study may be approached. As has been stated, many public school teachers are interested in teaching the biological and sociological aspects of family $11 f e$, but lack the knowledge and sk1ll to teach both. The problem addressed here Is how to remedy this inadequacy. A teacher's particular challenge may be to include family life materials in his present area of specialization. The areas of health, blology and social studies are examples. Dr, the task may be to teach family life as a separate unit or course. The most intensive plans may include both. Each school system, or even each school within a system, may be unique in its family iffe education design. The lack of state norms for family life teacher preparation contributes to the present situation.

The first purpose of this study is to demonstrate that the descrtbed pedagogical problem of teacher inadequacy in the family Iffe area exists in a selected metropolitan area. Secondly, a plan is provided for family life teacher in-service education. The basic goal of the plan is the enhancement of the ability of interested primary or secondary teachers to teach both the blological and socfological aspects of family life. Pertinent information and assistance in its comunication are basic components of the program. Thus, it is hoped to aid in remedylng the problem of teacher inadequacy in the fanily life area.

Unless designed for a specific school, family life in-service education must be presented in a versatile, loosely structured format. . One reason for this requirement is the already mentioned unique approach to family life education of each district or school. Furthermore, inservice teacher education requirements vary within each district. In 
addition, the provision of such a loosely outlined program is hoped to foster a creative approach to in-service education. Schools using the plan are provided with a wealth of materlal and a general philosophy for its use.

Purpose, form and content of teacher in-service education varies from school district to district. Therefore, this proposed program may serve only as a springboard for locallzed action. Ideally, the program Is seen as a vehicle for the in-service education of the entire staff within a particular school. Some schools are already using this method for teacher knowledge and skill enhancement in other areas of education. Such a school would have as its goal the enhancement of each teacher's contribution to family life education. In addition, one or more teachers may assume specific responsibility for family life units or courses which would reach every member of the student body. Th1s sort of cooperative effort could be most successfully guided by a person specially prepared in fantly life education.

Recognizing these special considerations, the purpose of this paper Is to investigate the existence of, and propose an aid in remedying the pedagogical problem of teacher Inadequacy in the described family life education area. 
II

RESEARCH INTO SOME OF THE CONDITIONS SURROUNDING THE STATED

PEDAGOGICAL PROBLEM AS FOUND IN A METROPOLITAN AREA

Fanily life education as defined for this study is not yet available to the entfre population of any one school within the central school district of the metropolitan area surveyed. In some of 1 ts suburban school districts various programs are belng developed with the hope of eventually reaching all students, kindergarten through twelfth grade. For Instance, one suburban school district in the summer of 1967 designed a program for grades one to eight. Teacher in--service education is not yet a part of the plan.

In the central metropolitan school district plans are being made to improve family life education through the work of health teachers. All boys and girls are reached by the health classes. Tamily life information has been traditionally dealt with in the districts' homemaking classes which are requtred only for seventh and eighth grade girls. Typically, a home-management approach to family Iffe has been taken in these classes. An In-service teacher education progran has not yet been designed to mesh with proposed curriculum changes.

Implementation of an educational program 1s, in part, dependent upon the skill of its teachers. The purpose of the research reported here is to reveal some current conditions of teacher family life skills and problems in the metropolitan area under scrutiny.

For two reasons emphasis upon sex education aspects of family life will be made in this section of the study. First, sex education is an 
emotionally charged question which has received much attention from the area residents in the last two years. Secondly, it is a fleld in which teachers apparently often feel inadequate. In addition, since the family life fleld includes many topics it was decided to turn attention here to this espectally important one.

In-service education for teachers of family life as stated earlier, however, requires a balance of sociological and biological materials. A goal of the program attached to this study is to meet this need.

\section{SOME PRESENT CONDITIONS RESEARCHED}

Surveys of Recent Community Sessions Involving the Sex Information and Education Counc1l of the United States (SIECUS)

Early In 1967 Dr. Mary S. Calderone, executive director of the Sex Information and Education Counc1l of the United States (SIECUS, appendix, A.), explained to Portland educators how satisfactory sex education progresses. It specifically begins at birth, she said, and, In addition should be integrated with the school program, kindergarten through twelfth grade. Formal emphasis is required before puberty and also later in the school curriculum. She was immedlately asked by those same teachers, "...but when should sex education begin?"

Half of the forty-eight questions asked by the teachers sought further Information for teaching, but thirty-seven per cent asked questions which had fust been answered by the speaker. The remaining questions were concerned with symptoms of soclal problems or physical acts such as homosexuality, masturbation, divorce and premarital pregnancy. The1r questions revealed a feeling of Inadequacy for the 
task of family life education. Several seemed to think a good textbook would at least partly solve the problem, but others stressed communication difficulty.

TABLE I

PORILAND TEACHERS' QUESTIONS ADDRESSED TO DR. MARY CALDERONE FOLLOWING HER LECTURE ON "SEXTALITY"

$N=48$

Questions revealing teachers' concern over lack of Information and skills ....... . . 50\%

Questions asked which had been previously answered by lecturer .............. . 37\%

Questions showing concern over symptoms or physical acts (homosexuality, premarital intercourse, masturbation, divorce, etc.) ....... 13\%

Parents repeated the teachers' pattern of questioning when Dr. Calderone spoke to their even larger group. The predominantly female audience was concerned with who should teach what and when (a1though these questions had been answered in the lecture). Venereal disease and premarital pregnancy were the topics of many queries. Questions relating to decision making were few and those asking for factual information were negligible. 
TABLE II

PARENTS" QUESTIONS ADDRESSED TO DR. MARY CALDERONE

FOLLOWING HER LECTURE ON "SEXUALITY"

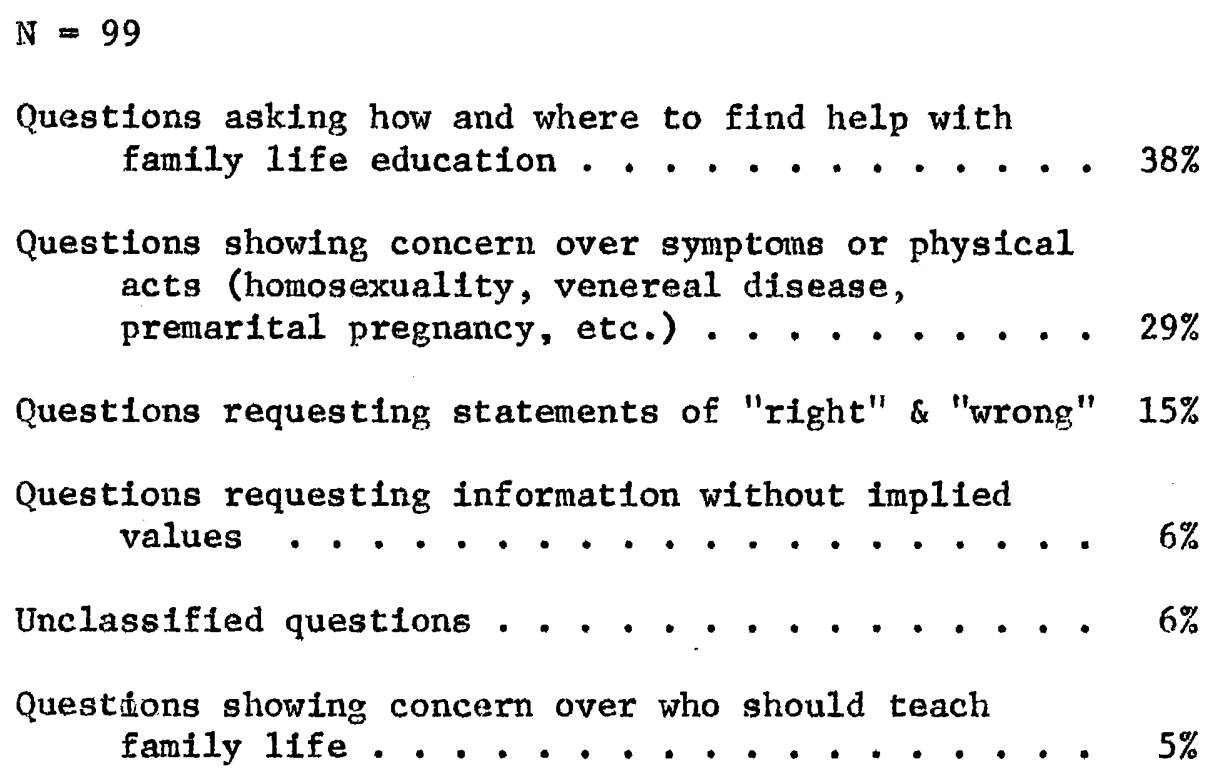

Student questions submitted following Dr. Calderone's talk on sexuality to a boy's technical high school student body may be placed in two predominant categories: Demand for specific facts regarding male and female sexuality and assistance in establishing values and attitudes required in making decistons for solving interpersonal problems. Her talk made no attempt to give human reproduction facts but dealt with the latter area. 
TABLE III

MALE TECHNICAL HIGH SCHOOL STUDENTS' QUESTIONS ADDRESSED TO

DR. MARY CALDERONE FOLLOWING HER LECTURE ON "SEXUALITY"

$N=205$

Questions requesting Information without Implied

values . . . . . . . . . . . . $61.9 \%$

Questions requesting the speaker to set a standard,

i.e. of right and wrong ........ $32.2 \%$

Questions questioning speaker's position ..... $1.5 \%$

Questions requesting further explanation of a statement ..................... $0.5 \%$

Facetious questions ........... $3.0 \%$

\section{A Study of Parent Groups' Responses to Proposed Fanily Life}

Education Programs

Another adult audience from the same metropolitan area, voluntarily viewing films for child and adult sex education, was most enthusiastic about the primary level film, Human and Animal Beginnings. Two other films were shown, each progressively more frank. The last f11m discussed masturbation. These two films were recelved with somewhat less enthusiasm according to a questionnalre. Sixty-four of the total of sixty-seven parents would like their child to see the first film, thirty-six the second and only eighteen the third. Dissenting parents were concerned with the film's fallure to inculcate values and feared that it would encourage children to "experiment". 


\section{PARENTS' RESPONSE TO FILM VIEWING}

F11m 1. Human and Animal Beginnings (primary leve1) Natural science scenes of baby monkey, newborn guinea pigs and rabbits while preb1rth growth and development and birth itself are handled in animation.

76\% of the parents felt that they themselves benefited from seeing the f1Im; $90 \%$ felt that their children would benefit. $89 \%$ sald that they would like their child to see the film. $(N=72)$

Film 2. Human Growth (Intermediate level)

Known as the $\mathrm{E}$. C. Brown "Oregon F11m". Reproduction and birth in animation.

$69 \%$ of the parents felt that they themselves benefited from seeing the film; the same proportion thought their children would benefit. $61 \%$ sald that they would like their child to see the film. $\quad(N=65)$

F1Im 3. As Boys Grow (Intermedlate level) Deplcts a serles of locker room talks between a coach and members of his track team regarding early adolescent sex and development problems. Masturbation is included.

$57 \%$ of the parents felt that they themselves benefited from seeing the f1lm; $43 \%$ felt their children would benefit. $27 \%$ sald that they would like their child to see the film. $(N=61)$

\section{A Study of Sex Role Attitudes of Contrasting Student Groups}

A study was made of attitudes of girls from the metropolitan area who are day-school drop-outs, mostly for reasons of pregnancy and/or marrlage. It shows that these girls regard the satisfaction of male needs as their primary female purpose in 11fe. Yet, these same girls express distaste or boredoin with their sexual experience and are frankly 
surprised that a class member enfoys or misses a sexual relationship. Again, these students are convinced that the feminine lot is to "give sex for love" while the male "gives love to get sex". In contrast to this double standard of sex, however, the girls feel they should be able to take care of themselves and make their own decisions. Statistical information shows that in spite of this trend, more day-school drop-outs than other students questioned belleve women should be cared for by men. In contrast there is no correlation between the girls' belief that their purpose 1s to meet the needs of men and their lack of bellef that a woman must marry and have chlldren in order to reach personal fulfillment.

TABLE V

STUDENT ATTITUDE SURVEY

Respondents answered questions on a scale of t3 (strongly agree) to -3 (strongly disagree)

Woman's purpose in life is to fulfill the needs of men. $\begin{array}{lll}\text { Evening High School girls } & N=38 & +1.05 \\ \text { Day High School girls } & N=22 & +0.95 \\ \text { Single College freshman girls } & N=30 & -1.00 \\ \text { Single College freshman males } & N=33 & -0.94\end{array}$ A woman must marry and have children in order to reach complete fulfillment in life. Evening High School girls $\quad N=38 \quad-0.21$ Day Figh School glrls $\quad N=22 \quad-1.09$ Single College fresiman girls $\quad \mathrm{N}=30 \quad-0.63$ Single College freshman males $\quad \mathrm{N}=33 \quad-0.76$

Women should be submissive to mens' 1deas of what is right. Evening High School girls $\quad N=36 \quad-0.69$ Day High School girls $\quad \mathrm{N}=22 \quad-1.14$ Single College freshman girls $N=30 \quad-1.53$ Single College freshman males $\quad N=33 \quad-1.73$

A woman needs a man to take care of her.

$\begin{array}{lll}\text { Evening High School girls } & N=32 & -0.84 \\ \text { Day High School girls } & N=22 & +0.50 \\ \text { Single College freshman girls } & \mathbb{N}=30 & +0.10 \\ \text { Single College freshman males } & N=33 & -0.33\end{array}$


A Study of Federal Maternal Clinic Patients' Response to One Aspect of Family Life Education

Research (fa1l, 1966 - winter, 1968) was done at a federal maternal care clinic in the metropolitan area where nearly half the patients are premaritally pregnant and all are classed economically under-privileged. Sixty-five per cent of the one hundred patients surveyed, after counseling and delivery, were still poorly informed concerning conception and contraception. A well informed patient was considered one who understood how she became pregnant and how she could avold an unwanted pregnancy.

After highly skilled one-to-one counseling while still in the maternity ward, a period of high motivation, elghty per cent of these women kept appointments at a federally sponsored family planning clinic. Half of those not keeplng their first appointment came after a follow-up consultation. A slightly smaller proportion of the previously poorly informed compared to the previously well informed kept appointments after the initial one-to-one counseling. The number of women not wanting information assistance was negligible. Lack of expressed Interest was usually due to religlous afflliation. Other patients not seen by the family planning team were those petitloning for tubal ligation, surgical sterilization which has become very popular with clinic patients in the last year.

One hundred patients were surveyed for the state of their reproductive and contraceptive information while in a maternity ward. One year later they were surveyed again to determine whether their contraceptive clinic appointment schedules were maintained. 
Although a higher percentage of previously well informed than previously poorly informed patients kept their appointments, for a level of .05 significance, the difference is not significant. A contral group of one hundred patients not given one-to-one coungeling would be necessary in order to show the real value of the project. Unfortunate1y, a control group was not avallable. Clinic personnel did feel that considerable improvement had been made over the past showing the value of the intensive education program.

TABLE VI

FEDERAL MATERNAL CARE CLINIC PATIENTS

\begin{tabular}{|c|c|c|c|c|c|}
\hline & \multirow{2}{*}{ Total $N=100$} & \multicolumn{2}{|c|}{ Kept Appointments } & \multicolumn{2}{|c|}{ Did Not Come } \\
\hline & & $\tilde{N}$ & $\%$ & $\mathrm{~N}$ & $\%$ \\
\hline $\mathrm{N}=35$ & Well Informed & 31 & 89 & 4 & 11 \\
\hline$N=65$ & Poorly Informed & 49 & 75 & 16 & 25 \\
\hline
\end{tabular}

\section{Contributions of Textbooks and Other Materials}

Within the metropolitan area surveyed textbook contrasts are found In a suburban school district. The system is called one of the most progressive in the state. The seventh-grade science text ${ }^{2}$ indexes fertilization in ferns but not in humans: reproduction in reptiles but 
not in humans. In al1, thirteen forms of life are 11sted under "reproduction" in the index. Man is called a mammal in that section of the text, however, and the student is allowed to Infer through default that man nust be a placental creature in which the female egg is internally fertilized by a male sperm. In like spirit the charts of human anatomy deplct neuters, otherwise possessing male characteristics. One inay find in used texts efforts of amateur artists to correct the oversight. Locations of all hormone secreting glands are stated except those of the "sex glands" as they are called in the text. An elementary description of their function is outlined. This is the text used by students, most of whom have entered puberty.

Sophomores in the same school district use a text ${ }^{3}$ containing drawings of male and female reproductive systems and ChIld Birth Association models of prenatal growth. One instructor told his classes of the publisher's experimental effort to use the text. In at least one city, he said, the parents got up a comittee and blacked out the reproduction charts. But the teacher chose to use the illustrations for a basis of class discussion. He made up work sheets on pink and blue paper.

Despite the dearth of sex education information in standard classroom texts there are ample teaching materials avallable. Many are Included in the in-service education program attached to this study. A wide range of intents and purposes can be observed in them. Teaching units, books, pamphlets, journals, films and film otrips are designed for all age levels. Basic intent of these materlals ranges from highly moralistic to technical. 
Examples of Teacher Inadequacy

Less skilled and poorly informed teachers may rely upon well intended information of a threatening or 111-founded nature. One recent Instance in the metropolitan area concerns a member of a comittee for writing a sex education curriculum for her school district. She told the writer of her huge success with including the dangers of venereal disease in her warnings about premarital sex. This was proven when one girl in the non-coeducation group said with great emotion, "The next time a boy with zits on his face aske me for a date I'11 sure turn him down in a hurry!" Another teacher in a large high school reported her girls were very receptive to her phllosophy that women give sex to get love and men give love to get sex. A man in an elementary school last year was proud of having taken his boys aside and assuring them they should be very selective about thelr chofce of events for sexual intercourse since thelr 1ffe--time capacity "has its linits to just so many times."

SOME RECENT ORGANIZED ETFORTS TO CHANGE EXISTING CONDITIONS

\section{Nationa1 Leve1}

Mentioned earlier, at the national level is a new voluntary organization which claims a positive approach to family life and sex education, the Sex Information and Education Councti of the United States, (SIECUS). (Appendix, A.) This organization offers its service to the fleld of education. Founders of the organization say they are not motivated by a goal of improved "morality" but rather the 
"establishment of man's sexuality as a health entity". Several prominent sociologists are members of its board of directors. Dr. Jessie Bernard, Pennsylvania State UnIversity, is a vice president. Also at the national level. ts federal administrative finterest in the promotion of family life information through the Health, Education, and Welfare department. The results of this may be seen in several ways at the state level, for the most part as preventative measures for women liable to unwanted pregnancy. Special funds are also nov avallable for college level in-service family life education workshops.

\section{Loca1 Leve1}

New, at the county level, is the one-to-one counseling of men and women for fertility control assistance. Th1s service is now avallable In the metropolitan area under study here. About half of the state's counties were represented early in 1967 at a three-day Health, Education and Welfare department - State Public Health Association family-planning seminar.

There are several voluntary organizations, mostly religiously orlented, giving twenty-four hour care and schooling to unwed mothers in the metropolitan area. To leave home and live in one of these institutions is the only way a fifteen year old pregnant girl may continue her studies. Some of these groups help the girls understand the birth process before their dellvery but none provide girls with contraceptive help. Their goal is rehablittation which, they belleve, would be hindered by knowledge of contraception. Many of these girls come to Planned Parenthood Assoctation clinics where information and medical 
contraceptive help is made available to them if the course of their iffe Indicates repeated danger of pregnancy. Some become pregnant again. They may then become patients of the local federal maternal-care clinic. Some are among the patients surveyed in this paper. Because of client mobility, rehabliftation percentages are not known.

The state's "Sex Education Program" (Appendix, B) outlines briefly the history of the State Department of Education's association with the E. C. Brown Trust. The trust is a long-time sponsor of sex education materials. The accompanying "personal hygiene" and "family living" outlines are suggested for an age period after having entered puberty. These outlines have also been written from a perspective of "life adjustment" to things as they "ought" to be. A soctal psychological approach to human development is lacking. The bibllography is in need of updating and there is no mention of population and fertility problems. The paragraph of the outline referring to implementation reads: "The extensiveness and depth to which this subject is pursued is more or less left to the discretion of the local school administrator, with the availability of qualffied and interested teachers as a final determinent."

The central metropolitan area school district was one of the sponsors of Dr. Calderone's 1967 lectures already mentioned. A comittee is now working on an integrated approach to family life education for the district. This means a distribution of appropriate information for each grade level. As stated in the introduction to the preceding research section, thus far a coordinated program has materlalized in the city's health classes in correlation with the Individual 
teacher's ability. The school district has provided teachers with some workshop type fanily life education opportunities but, according to the health education supervisor those have touched only a few teachers. 4 The district has a resource materials list which is belng improved. Success of their program depends upon its goals and the ability of the teachers to relate to those goals and bring them to their students. Finally to be noted are the activitles of local medical and educational organizations. The Board of Trustees of the state medical association at their March 1967 meeting resolved to support proposed legislative measures whlch would permit physictans to perform abortions necessary to the mental and physical health of their patients. Only if the mother's Iffe is in question may abortion now be legally performed in the state. This is the first time the association has officially voiced an opinion on nodifying the state's abortion laws. 5

In the last year a committee of the metropolitan area medical society has been working to assist educators with sex education material. The medical society was a sponsor of Dr. Calderone's visit. Spring of 1968 a group of specialists were instructors for a college level course, "Human Sexuality". 6

In 1965 Continuing Education sponsored for the metropolftan area a three-day working conference, "Love in Contemporary Society." The program was a "pot pourri" of topics ranging from the showing of the film, The Lovers, with a discussion of its portrayal of contemporary woman, to Dr. Alan Guttmacher's lecture on contraception. (Appendix, C) Another speaker deplored the "dichotomy of sex and love." Winter of 1966 the areas' educators were invited to a one-day seminar, "Sex 
Education Guidelines In A Modern Soclety", featuring a lecture by Dr. Lief of SIEcus. (Appendix, D) The county medical society, the local state college, and the clty public school district were conference sponsors.

\section{A Community Pilot Program}

The Longview schools in the state of Washington are used by SIECUS as an example of how communtty effort gained public support for family Iife education. As described in the superintendent's letter to the writer, teacher preparation has been a problem. For the time being it. is partially solved by awarding teachers in-service credit for attending workshops which are also open to the public. The inadequacy of teacher preparation and resulting lack of continuty are apparent in the superintendent's expressed dissatisfaction. (Appendix, E)

GENERAL CONDITIDNS SURROUNDING FAMTLY LTFE EDUCATION AS VIEWED BY CURRENT LITERATURE OF THAT FIELD

Probably the most recent and complete sumnary of current conditions surrounding family life education as seen from the professional level appears in the May, 1967 1ssue of the Joumal of Marriage and the Family. ${ }^{7}$ Here sex education is seen as an important part of family life education. A wealth of available but uncoordinated materials is noted. Therefore, it is stressed, the real need is for teachers sensitive to the teachable moment. The teachable moment often occurs at the most unexpected time in an ongoing classroom situation. Skill at such a moment would permit the teacher to deal effectively with his own 
feelings. This teacher would be well grounded in both biological and sociological aspects of human relations. He would then be able to communicate constructively with his students.

There remains the question of just how to include fanily life materials in the school curriculum. Two methods are discussed in the journal: 1. as a subject-matter course in 1tself, or 2. as an integrated part of subjects already taught in the schools. In either case, the journal report states, teacher preparation is both cruclal and lacking. And, it is that very preparation which would determine how well and how successfully teaching materials are used.

Dealing specifically with sex education, the Winter, 1968 , issue of SIECUS Newsletter discusses its primary need - teacher preparation. ${ }^{8}$ Most other problems surrounding sex education become minor, we are told, if the "right" teacher is found. SIECUS sees a dramatic increase in teachers asking for help in meeting this need. Three neans of answering their request with in-service education are given: 1 . supplying current thinking related to a solld factual content of blological and sociological material; 2. helping teachers cope with their own attitudes which may inhibit their ability to teach; and 3. actual experfence with conducting a dialogue--centered classroom. The sIECUS writiers conclude, the ultimate purpose is the development of teachers who, as John Chandler, Jr. of National Association Independent Schools (NAIS) has stated, "...can meet youngsters where they are with frankness and honesty, and can discuss their concerns obfectively and non-judgmentally with them."

The most pertinent professional literature agrees with the theme of 
this study. That is, those responstble for teacher preparation must concern themselves with teacher inadequacy for the requirenents of family life education. Fanily life education includes both biological and sociological knowledge. The abllity of the teacher to communicate skillfully is cruclal to the task.

\section{SUMMARY OF CONDITIONS RESEARCHIED}

1. There are anple but uncoordinated teaching naterials avallable for family life education:

2. These materials include both units of instruction and supplementary aids.

3. Many teachers want to use them but feel Inadequate to the task.

4. Some teachers unwittingly teach mis-Information.

5. Students want information and are eager to communicate a wide variety of concepts.

6. Teachers are fearful of communtcating to young people the concepts with which they do not agree for fear of causing the young people to accept those concepts.

7. Many teachers lack a social psychological perspective of human development.

8. Many teachers lack a full understanding of the biological aspects of family life education.

To sumarize, teacher information lack and communicative skills handicaps are deterrents to the teaching of both the biological and soctological aspects of famtly life. Well designed teacher in-service education can do much to remedy teacher inadequacy as it is described in this study. 
III

HOW CAN THE DETERRENTS TO TEACHING BOTH THE BIOLOGICAL AND THE SOCIOLOGICAL ASPECTS OF FAMILY LIFE IN PRIMARY AND SECONDARY SCHOOLS BE MODIFIED?

It should be noted here that Section III has a dual purpose. Initlally it performs as a final section of the preceding sections of the thesis to be concluded by Section $V$, Thesis Summary and Conclustons. However, since the additional need for an actual teacher in-service famlly life education outline is to be met, Section III has a second function. Section III also serves as a forward to "An In-Service Education Program for Teachers of Family Life Education from A Soclological Viewpoint", Section IV. Therefore, Sections III and IV may be IIfted from the thesis to be applied directly in a fleld situation.

Both the professional 1iterature and the preceding research reveal the pedagogical problem of teacher Inadequacy to the family life teaching task. The Inadequacy has been described as both one of know1edge and of skill. A fine rapport between student and teacher, as in any other area of education, is essential but not enough to fill the void. Specialized knowledge and skills are also a prerequisite. An inservice education program for teachers of family life is proposed here in at least partial solution of the stated problem.

The sumnary of conditions researched is indicative of the requirements of an in-service program designed to modify deterrents to teacher. 
adequacy. Such a program would organize the presentation of appropriate materials in such a way as to assist teachers in developing communfative skills. Initially, however, the specific kind of education program most salient to these goals should be considered. As indicated, teachers are faced with an ample but uncoordinated mass of family life materials. The in-service program would necessartly then provide a suggested outline of materials. Such an outline could be further augmented by some method of critical analysis. Since the research shows adults have much difficulty in separating their emotions from family Iffe Information, especially the area of sex, sociological techniques for developing an analytical approach seem pertinent.

It has been stated that many teachers lack a social psychological perspective of human development as well as a full understanding of the biological aspects of famfly life education. Both of these voids must be filled by the in-service program. Materials would need to be drawn from both the social and phystcal sciences. For example, after gaining an understanding of both social and physical human development theories teachers would study social institutions as they relate to the bastc family institution.

Even though pertinent information and a means of objectivity have been suggested for the in-service program the need for teachers to exercise cominunicative skills remains. During the communicative process Inhibiting attitudes can be brought to awareness as well. As stated earlier, actual experience in conducting a dialogue-centered classroom is a realistic answer. This means the in-service program would evolve as an application of a social psychological theory of communication. 
This theory would be considered as being basic to human interaction and therefore basic to human developnent. Presentation of sociological and biological information can then be more adeptly placed in an ongoing interactional frame of reference.

Thus, it is proposed, teacher information lack and communicative skills handicaps, deterrents to teacher adequacy in family life education, can be modifled through the in-service education of teachers. The pedagogical problem of teacher inadequacy to the family life teachling task is thereby served. 
AN IN-SERVICE EDUCATION PROGRAM FOR TEACHERS OF FAMILY LIFE EDUCATION FROM. A SOCIOLOGICAL VIEWPOINT

WHAT KIND OF EDUCATION FOR FAMILY LIFE?

The effectiveness of family life education is subject to the same problems as other attempts to change attitudes and behavior by means of educational processes. There are many studies that indicate the difficulties and areas of success or posstble failure of such programs.

There have been studies evaluating the salience of education in lessening prejudice. Vander Zanden reviewing such studies finds little use for education as a prejudice-lessening instrument. However, in quoting $R$. M. MacIver he fails to note that a particular kind of education is named. MacIver says, "All we can cla1m for instruction of a purely factual kind is that it tends to mitigate some of the more extreme expressions of prejudice.9 Education of a "purely factualkind" is only a part of genuine education.

Two problems arise here in relation to the purposes of family life education. First, is our purpose to change the educational condition? Second, do we propose to supply students w1th facts, and if 80 , what facts? We shall delay answering our questions and first briefly consider overall goals of teaching methods.

As Jerome Bruner has sald, we must reconsider what it is we do when we occupy student's time for such long periods of what we call "schoolIng". He speaks of arranging environments to optimize learning; that one teaches readiness or provides opportunities for its nurture rather 
than simply waiting for $1 t .10$ Then what happens to an Individual in an educational setting is a social phenomenon. Clearly, the teacher is a part of the event.

Bruner clarifies the teacher's responsibility when he concludes, "...that discovering how to make something comprehenstble to the young is only a continuation of making something comprehensible to ourselves in the first place - that understanding and aiding others to understand are both of a piece." 11

In answer to our two above questions, then, we submit that our first concern is with the educational condition. The second intent is to assist students, through building our own comprehension, in reflecting over the varieties of contemporary concepts of family life.

Parents and teachers continue to be concerned with teaching values and building attitudes. The concept that family and sex education begins at birth is most difficult to grasp. Frobably many fall to realize the nature of their own decision-making in these areas. They may be unaware that they are: 1. accepting socially determined absolutes as guides and attempting to enforce them with threats; and/or, 2. helping young people gather infornation which they can apply to situations requiring personal dectsions. Elther process may come up with the same answer; the decision-making process does not determine the answer. The first requires unfailing faith in an accepted conviction designed to keep things as they are or "ought" to be, while the second requires much knowledge and thought to its application. Both would involve perspectives, values and attitudes gained through life-long experience. The second process requires more depth and variety of experience than the 
first. The kind of education proposed here for teachers of fainlly life places an emphasis on current information and 1 ts open and frank communication within the classroom.

\section{COMMUNICATION THEORY AND FAMILY LIFE EDUCATION}

Communication as a vehicle of understanding, and more fundamentally as the source of human qualities, is important to our discussion of the nature of family life education. Though always recognizing language as essential to human interaction, psychologies of human development differ In their description of the role of communication.

The requisites of communtcation are the same in the classroom as those in every other human situation. The communicant and the communicator must share the meaning of the message in order for it to be received as intended. Feedback is essential to assure the communicator the process is taking place. The first requisite may demand a very special effort on the part of the teacher. Often a teacher represents a much different background of experfence than that of the student. A special effort is made here to provide the family iffe education outline with constant opportunity for teacher to student and student to teacher message sending, receiving and feedback.

Our research has shown that both parents and teachers are apprehensive about the effect of family life education. From what he describes as a mass communication viewpoint, Klapper provides a few tentative emerging generalizations after a survey of a large quantity of pertinent research. From these generalizations he develops hypotheses of some Interest to our problem. We must remember that a fact to face situation 
would modify the effects of mass communication depending upon the teacher-student rapport.

\section{Klapper generallzes:}

1. Mass communication ordinarily does not serve as a necessary and suffictent cause of audience effect, but rather functions among and through a nexus of mediating factors and influences.

2. On such occasions as mass communication does function in the service of change, one of two conditions is likely to exist. Either:

a. The mediating factors w11l be found to be inoperative and the effect of the media will be found to be direct; or

b. The mediating factors, which normally favor reinforcement, will be found to be themselves impelling toward change. 12

Medlating factors and Influences offered by Klapper are organized around television watching and other media particlpation by children and are only suggested here for possible relevance to the classroom situation. There does exist a similar "child in the adult-designed" atmosphere in the two settings. The same potential for the presentation of new issues is available. In the classroom the conditions for communfication are enhanced by feedback. An additfonal enhancement of cominunicative possibilities in the classroom is offered by the teacher's ability to vary activities to meet specific occasions as they arise.

In particular reference to Information of an adult nature, Klapper suggests that children already possessing firm Ideas will be In a sense insulated from the effects of further information and resist conversion. Furthermore, "Where such mediators are absent or inoperative - as in the case of children without previous knowledge at hand - television is found, as proposed..., to exert at least a temporary influence". In 
this case then, Klapper belleves opinions may be created on new issues. 13

Variables likely to be involved in the medlating forces above Include the behavior of adults in the child's primary group and their ablity and willingness to communicate with the child on subjects of interest to him. It has been documented that when insulating forces are Inoperative in an area where a child has interest and very little information a new source of information will be attractive to him.

It has already been suggested that teachers approach the teaching of family life material from a process perspective. However, a warning is called for at this point. Contrary to the expressed desire of. parents that teachers teach values, 1.e., speciflc values, the intent here is that teachers help students realize a choice of values and consider their variable implications. In order to do this the teacher w111 need to maintain an open attitude toward the two central psychologles and their parallel social theorfes. Should one be perceived as being given preference to the other the value of both categorizing Instruments may be lost. Communfation theory supports this possibility In that salient student-teacher rapport could result in the teacher functioning in the influenctal role of an oplnion leader. 14

\section{COMMUNICATION AND PSYCHOLOGY RELATING TO FAMILY LIFE EDUCATION MATERIALS}

As stated earlier, communication is not only a vehicle of understanding, but the fundamental source of human qualities. The "symbolic interactionist" theory applied as a flexible interpretation of role in "conflict" sociologies is a melding of these two aspects of communication. 
Lindesmith and Strauss base an entire soctal psychology upon man's uniqueness anong creatures which results from his language ability. Lindesmith and Strauss write:

...the distinctive attributes of human behavior, which grow from man's immersion in a cultural environment, depend upon the extstence of language behavior, or the creation and manipulation of high-order signs (symbols). Soctety means communication. Language is both the vehicle by means of which culture is transmitted from generation to generation and also an integral part of all aspects of culture. The features of human behavior which distinguish it from the behavior of other animals are derived from the fact that man is a symbol manipulator - the only symbol-mantpulating animal. Complex forns of social organization, institutions, codes, beliefs, and customs - indeed all cultural phenomena - depend upon and are made possible by the prior evolution of language. Language behavior, epitomfzed fn conversation, is a learned form of interaction which has its blological basis in the nature of the human brain. 15

In contrast there are theories of human development which grow out of some blologically determined characteristic or set of characteristics which in themselves set the actual course of man's actions. Rather than providing possibilities of interaction, these theories are homeostatic In perspective. In application such a concept seeks to discover why man does not behave as he might should he follow some prescribed formula. Both begin with blological "givens" but follow a different course of development. One seeks repose, the other follows infinite process. An example of the repose or equilibrium-seeking of a psychology is found in Freud's Civilization and its Discontents:

...Men are not gentle, friendly creatures wishing for love, who simply defend themselves if they are attacked, but,... a powerful measure of desire for aggression has to be reckoned as part of their instinctual endowment. The result is that their neighbor is to them not only a possible helper or sexual object, but also a temptation to them to gratify their aggressiveness,....to seize his possessions, to hunlliate him, to cause him pain, to torture and to $\mathrm{kill} h i m ; . .$. who has the courage to dispute it in the face of all the evidence in his own life and in history? 16 
In the preface to his Three Essays on the Theory of Sexuality Freud states that in takfing the challenge of psychoanalysis he has purposely Ignored biological research. 17 Masters and Johnson quote Freud from st111 another writing where he calls the science of biology unlinfted. Furthermore, he says, it may surprise us in the near future with new Information, "...whtch will blow away the whole of our artffictal structure of hypothesis." 18

The social psychology of Lindesmith and Strauss is based upon the work of George Herbert Mead. Mead contrasts the Individualistic and the soclal theories of the self. The first is typified here in the work of Freud and the second by the symbolic interactionist school derived from Mead. The Indivfdualistic propositfon, "...assumes Individual selves as the presupposttions, logically and blologtcally, of the social process or order within which they Interact." The other type, "...assumes a social process or soctal order as the logtcal and biologtcal precondition of the appearance of the selves of the individual organtsms involved in that process or belongtng to that order."19

Because Mead's perspective assumes the alternate taking of roles, or the att1tude of the other, and is not seeking a correction of balance gone awry, it is especially sulted to the classroom atmosphere sought here. As portrayed by Mead, this sort of activity lies entirely inside the child's own experfence and is quite posstble within the classroom. 20 In explanation, we shall return to the deciston-making process. If role is considered a static part of an ordered human condition, Irregularity from the glven norm becomes deviation and is therefore disruptive to that order. Should this concept be a part of our 
perspective of the human condition, declsions based upon the maintenance of tradition and its accompanying absolutes would seem wise.

Mead's view of roles in human interaction, in contrast, presents the human condition as an ongoing process typlfied by emergent properties. Innovation, rather than deviation, is anticipated in the flux of human interaction. This is not to say there is no "fit" to human interaction. Quite to the contrary, decision-making of a thought-out sort becomes most important if one is not to rely upon predetermined norms in all situations.

Facets of life characterized by rapid change are especially suitable to the latter perspective. One of our goals in the family life education design is to provide an environment cordial to a flow of alternate taking of roles, assuming the attitude of the other and placing one's self within that environment.

CONTRASTING PSYCHOLOGIES ATTACHED TO SOCIOLOGICAL PERSPECTIVES FOUND IN

\section{FAMILY LIFE MATERIALS}

Peter Berger calls the "reality" to which we usually refer a "very precarious one indeed". 21 In vlewing society as an ongoing drama he takes a stance derived from that of Mead. In the passing scene he does not deny the actor is constrained from both without and within, But all the same, he says, the actors have options, "...of playing their parts enthuslastically or sullenly, of playing with inner conviction or with 'distance', and, sometimes, of refusing to play at al1." He contrasts this human cholce with that of an animal following instinct saying, "I have no choice", and the lie of the human using the same defense against 
the perceived demand of soclety that he behave a certain way. 2.2

Another sociologlst, Talcott Parsons, has clatmed a very Important convergence exists between Freud's views on internalization (of roles) and that of Mead. However, Parsons' emphasis is on the relations between personality and the social systen which delegates role as the Instrument of the interpenetration of the two. Role becomes, "...the organized system of participation of an individual in a social system, with special reference to the organization of that social system as a collectivity."23 The ongoing process of the social scene is lost as the concept of role becomes lodged within a structure of parts functioning in relation to one another.

In his Social Structure and Personality Parsons only hints at something akin to Mead's use of communication and role. He uses the term "task" to 1dentffy the nore differentlated and highly spectfled activities which go to make up roles. Re calls the task a physical operation. In one sentence he dispenses with the comunicative implications. It reads, "It is very important that processes of communication, the meanings of which are by no means adequately defined by the physical processes involved at the task level, are not only included in the concept of task, but constitute at least one of the most important, if not the most important, categories of tasks, or of components of them.'24

Psychologies, as we have shown, place contrasting emphases upon communication. For the one, communtcation is human interaction; for the other communtcation is only instrumental to the development of other blological potentials. Soclologist, John Horton has suggested a pattern 
for placing the contrasting theories we have been discussing side by side in order to view them in relation to social problems. ${ }^{25}$ (Appendix F)

Although intended for the analysis of social problems, Horton's "paradigm for the analysis of conflict and order approaches to soctal problems" seems espectally well suited for use in family life education. Teachers may use it to aid their own ability to objectively present the varlety of family life materials to be found in in-service programs. The dichotomy can serve equally we11 as a secondary student instrument for categorlzing and analysis.

It will be noted that Horton's paradigm places "positive attitude toward the maintenance of social institutions" under "Order Perspective." "Positive Attitude toward change," is placed under "Conflict Perspective."

The terms "order perspective" and "conflict perspective" are used by Horton in the same sense as we have used the terms repose-seeking and ongoing process. The earlier descriptions of two decision-making processes, as involving elther adherance to absolutes or reasoned decision-making, may be fitted within these parallel dimensions.

Order theories equate individual adjustment to social prescriptions with a state of health; deviants are out of adjustment. Parsons defines health as, "...the state of optimum capacity of an individual for the effective performance of the roles and tasks for which he has been soclalized." 26 In similar vein, Freud said neuroses result from a lack of harmony among personality factors and their relationship to society. On the "conflict" side of the dichotomy Rollo May bluntly states that an adjustment is exactly what a neurosis is. 27 Gordon Allport 
claims many a patient's head may be filled with "Freudian furniture" and no more than their particular existential view of the world may be their problem. 28

Horton adds to these interpretations of the "conflict", or existential perspective, with the growth definition of health Implicit In Paul Goodman's appratsal of the causes of delinquency in Anerican society. Goodman asks, "Is the harmonious organization to which the young are inadequately socialized, perhaps against human nature, or not worthy of human nature, and therefore there is difficulty in growing up?"29

It is not necessary that we become involved in an either-or debate of Horton's "Paradigm for the analysis of conflict and order approaches to soclal problems". His critics seem content to debate the 1ssue in essence as the question of whether societal boundarles are maintained by coercion or consensus. There is no question but that his dichotomy of perspectives exists. However, one might well look for individual vacillation from one perspective to another.

Just such vacillation may be seen in the few family life related publications approaching academic integrity in the matter of what to teach. It should be emphasized here that the field of family life is an area in education where there is heated debate and real fear over teaching all available information. And to make matters only worse; it is information which students want badly enough to take books not belonging to them in order to get it.

An example of the "bind" in which educators and writers may find themselves, is given in Vermes and Vermes, Helping Youth Avoid Four 
Great Dangers. The incldent concerns fifty high school students invited to a seminar, "Human Reproduction and Preparation for Childbirth", at New York Medical College. They were given a summary of primitive attitudes toward sex and reproduction, and made familiar with modern obstetrical instruments and contraceptive pills. They saw a film of natural childbirth and visited a hospital maternity floor.

Then came the test. Were the adults really ready to talk on the students' terms or were they attempting to maintain norms through awe of adult status?

At the roundtable which concluded the seminar, the students' questions concerned their primary interests of premarital sex and premarital sex education. Although the panelists included a psychiatrist, marriage counselor, obstetrician, and biology teacher, these specialists found it almost as difficult as a layman might to answer the basic, direct questions of the young people.

When Dr. Malvina Kremer, the psychiatrist, explained that "one must equate the depth and desire for lastingness in a relationsh1p with the level of sexual contact," a boy inquired if that meant loving a girl made 1 t acceptable for him to have sexual intercourse with her. The panelists then said that real love must include a desire for a permanent relationshlp like marriage.

The boy now stumped the panelists with his concluding question, "Would you recommend then that if two 16 yearolds feel that kind of love they get married?" They were unable to give him a direct "yes" or "no" answer on that one.

The authors continue with the story of Fred and Mary Lou who engaged in premarital sexual Intercourse. Both were infected with a venereal disease from sexual contact with several other people. Further, Mary Lou was pregnant. The author fails to note that the relationship of these two young people bears little resemblance to that referred to by the young man in the seminar.

Next, the writers declare sex activity cannot be restralned merely 
with threats of disease and illegitimate pregnancy. Instead,

They must feel that waiting until adulthood is the sensible, right, and ethical thing to do, in our particular society, with our Judeo-Christian system of morals. In other societles other moral standards may prevall, but in our Western civilization, whth our late maturity, our prolonged educational preparation, and the scarcity and competition for jobs, young people are not able to accept the responsibility of a serious sexual relationship until they are out of their teens.

Another seminar student then asks how youth should divert their sex drives. The question is not directly answered. Instead it is advised that parents will have better results in their efforts to control teenage behavior by using suitable codes and keeping youth involved in such activities as conferences on human rights, winning 0lymplc medals and good-w111 tours.

Such occupled youth may, "...still make mistakes in their personal conduct; but they certainly have less time and inclination for 1t." 30 Recognition of the failure of absolutes to coerce youth flickers and fades. The writers never quite manage to approach their subject from the perspectives demanded by the young people in the medical seminar. Being shown obstetrical instruments and contraceptive pills is not the same as a frank discussion of interpersonal relationships and the realities of responsible use of the many methods of fertility control.

RIchard $F$. Hettlinger, assoctate professór of religion at Kenyon College, in a recent book recommended by SIECUS, writes from a theological point of view. He concludes with an unexpected verdict. He says ear11er,

The consequence (of traditional Christian teaching) is that Christians from Infancy are imbued with a point of 
view which is entirely inconsistent with the development of a mature sex 11fe. The fact that it is acknowledged that most of them will not attain the ideal (1.e., complete abstinence from sexual activity or its restriction to marriage) does not greatly reduce the sense of unconsclous fear and fallure. The achievenent of a balanced selfhood is made much more difficult by an in-built sense of incompetence and depravity. 31

He then concludes that young people, all people, should live as responsibly as possible in their relationships with one another and omit making judgments. His book contains much information toward thoughtful decision-making.

Another theologian, James Pike, writes for parents. He bluntly clarifies two alternatives: Hold information from young people in fear of encouraging them to experiment and depend upon intense use of absolutes; or, give thein all the information they want when they want 1 t and depend upon continued attention to strengthening their decisionmaking abilities. Neither task is simple for parent or child nor frequently accomplished. of the second, he concludes:

As in every other type of situation an existential ethic (if tt is really ethic, not just existential) calls for the exercise of more consclentious responstbility than does adherence to a conventional code. 32

In order to guide one's child in carrying out the existentlal ethic, Pike says a parent would be obligated to inform his child of: 1. Responsibility for bitth control; 2 , venereal disease prevention; 3. discretion (we are social creatures and nust live within society); 4. decent treatnent of one's sexual partner (1.e., Buber's I-Thou rather than I-It relationship); 5. the futility of "shotgun" marrlage; 6. legal abortion being sometimes a necessity; and that inftial sexual experfence brings to bear a new force as its "fruitage" which makes turning back 
difficult if not imposstble. 33

Lester Kirkendall agrees with nuch of Pike's stand but is critical of his fallure to develop his point of calling a desirable sexual relationship "sacramental"34 of recent writers probably Maslow" 35 and Watts $^{36}$ come nearer to developing such a viewpoint while Pike only mentions 1t. Kirkendall, with his interpersonal relationships concept drives to much greater depth than Pike in developing his existential ethic. In outline form his work is summarlzed:

BASIS FOR MORAL JUDGMENTS 37

Those actions, decisions, and attitudes are:

Right-Moral, which produce

1. Increased capacity to trust people

2. Greater integrity in relationships

3. Dissolution of barriers separating people

4. Cooperative attitudes

5. Enhanced self-respect

6. Genera1 attitudes of faith and confidence in people

7. Fulfiliment of Individual potentlalities and a zest for living

Those actions, decistons, and attitudes are:

Wrong-Immoral, which produce

1. Increased distrust of people

2. Deceit and duplicity in relationships

3. Barriers between persons and groups

4. Resistant, uncooperative attitudes

5. Diminished self-respect

6. Explo1tive behavior toward others

7. Thwarted and dwarfed individual capacities and dissolusionment

In concluding his 1961 study of the interpersonal relationships of 200 college level males who engaged in premarital sexual intercourse, he named eight "very powerful" soctal forces which, "appear to operate in such a way as to make it very difficult, if not impossible, to expect relationships of strength and integrity to result particularly from the 
more casual use of premarital intercourse." The question follows, would an existential ethic result in "casual sex"? Depending upon definition, of course, but certainly from the viewpoint of the actor, it seems unlikely.

KIrkendall's Impeding forces are sexual exploitation, communication difficulties, negative attitudes and values ("Irrational fear of sex makes objectivity and effective communication very difficult."), sex antagonisms and hostilities, blological and soctal sex differences, deficiencies in personal adjustments, an Irrational moral code and Inadequate socletal arrangements.

On the other hand, he says, there are "facllitating forces" serving to modify our attitudes and sexual practices. These are a growing objectivity toward sex, growing Insights into human nature, Increasing tolerance for sexual expression, increased control over consequences (the real problem now belng human fallure to use controls), avallability of advisory service, decline of the double standard and increasing research. 38

Is change within the institutions of marriage and family a negative factor? The question is nelther asked nor answered by Horton's material. iNor does Znanieck1 39 exactly answer the question when he writes, "...sociologists must postulate that some kind of objective order exists among all soclal phenomena and discard altogether the concept of disorder and other analogous concepts." Soctal order and change are one, he concludes. The cholce avallable to family life educators appears to be between open and frank discussion of all pertinent information, and stress upon malntenance of absolutes. 
Several applications of Horton's dichotony have been shown. Classroom use will be included within the in-service education outline and the annotated bibliography accompanying each of its ten sections. Again, Its use is not intended as a guide to "right" and "wrong", but rather as a catalyzing instrument for discussion of the wide variety of Ideas to which young people are exposed. Secondly, use of the dichotomy may help the teacher maintain objectivity in teaching.

PURPOSES AND GOALS OF THIS PROPOSED IN-SERVICE EDUCATION PROGRAM

1. The program is intended to assist teachers at all academic levels to integrate family life materials into their present subject matter and/or devote spectfic time segments to the area.

2. Teachers are encouraged to frankly evaluate their own stance as to their personal intention when presenting famlly life matertal.

3. They are offered a method of categorizing others' perspectives as revealed in the literature.

4. Teachers will be helped to realize the potential of their special field for contribution to family life.

5. Avenues for cooperation between teaching areas should be Indicated by classroom interactions.

6. Gaining objective perspectives of central human development theories is stressed.

7. An opportunity to acquire experience in discussing formerly difficult subjects is given.

8. An actual involvement in useful teaching techniques is the program vehicle. 
9. Teachers will obtain specific Information essential to sex and family 11fe education and 1ts sources.

10. Teachers will be helped to cope with their own attitudes which may inhibit their ability to teach.

11. Teachers will thus be enabled to frankly evaluate their ability to teach family life Information.

12. Teachers will both particlpate in a dialogue-centered classroom and galn experlence towards actually conducting a simllar situation with their own students.

In turn their students gain:

1. The spectific information they desire.

2. An understanding of the sex-love dichotomy.

3. An analytic approach to family life concepts.

4. Strengthened self-concept.

5. Enhanced perceptions, egpecially of interpersonal relationships with the opposite sex.

6. A view of marriage as a state which may be apart from family.

7. Affirmation of values already held, clarification of those which are unclear and Information for the formation of those yet to be established through the process of experience.

SUGGESTED TEACHING TECHNIOUES RELEVANT TO THE PRDGRAM OUTLINE

\section{General Philosophy}

If the answer is knowable, that which a child seeks to know, he must know. Such a philosophy places conslderable burden upon the teacher. While maintaining a clearing house for family life information 
the individual with a zest for teaching w111 continue a search for further knowledge. The resulting attitude becomes an integral part of the teacher as a signiflcant adult, nodel and communicator in the classroom.

Bruner has sald, "Who is not bble to recall the impact of some particular teacher - an enthusiast, a devotee of a point of view, a disciplinarlan whose ardor came from love of a subject, a playful but serlous mind?" The destructive Images he recalls as, "teachers who sapped confidence, the dream killers, and the rest of the cabinet of horrors". 40

Teaching techniques suggested here are intended to intellectually and emotionally involve teacher and student in the accompanying subject matter. Carl Rogers tells us, "The only learning which signfficantly Influences behavior is self-discovered" and this sort of learning cannot be directly communicated. 41 Educators may despalr of the lack of depth and breadth of the experiential fabric of many young people's lives.

But the teacher may need to expand his own perspectives in order to meet those of his students. For Instance, Rainwater, in recent family planning field research came upon a strong correlation of sharedness of husband-wife roles and rising socto-economic family status. 42 The husband who is involved in homenaking experiences is more interested in family planning than the man who is not. Knowing that lack of economic opportunity and resulting estrangement of husband-wife roles is a reality, especially among minority groups, the teacher can gain teaching relevance to certain student's 11ves. For example, what then is maturity to the Negro youth? What does feminine responsibility mean? 
Relevance can be accomplished with intent only by the teacher dipping into the boundaries of the student's own perspective.

The teacher, then, must be student as well as teacher. In a program of this kind he will be referee-moderator to a small coeducational group of students (preferably a maximum of fifteen) engrossed in sharing Ideas, sometimes to the heat of argument. His will be a constant vigil for openness and relevance.

\section{Teaching Techniques}

The teacher role is that of a moderator, the most widely informed inquirer and intent listener in the class, with a zest for new Information and its potential. The following list of teaching techniques apply to the instructor for the in-service course and are suggested for the school classroom as we11:

1. There is a vast quantity of reading materlal avallable on subjects relating to family life. None of it can be honestly considered worthless if the spirit of Inquiry is applied to 1t. Of course, some will yield more substance than others. The first question is: What are we looking for in our reading? Suggested Inquiry:

a. What process of decision-making does the writer seem to be using? 1.e., what is the intent?

b. Are his knowable facts correct?

c. How does his message relate to family life?

d. How does his stand compare with others on the same subject?

e. How could the teacher use this materlal? 
f. How might this materlal relate to other areas of the school curriculum besides that of the teacher in question?

g. Is the teacher's communication skill adequate to the use of this material?

2. Because there is such a varlety of material avallable, no one teacher or student could possibly read it all. Diversity will stimulate rewarding argument. Solution: Shared readings.

a. Early in the course sources of material are considered and an understanding reached for each teacher-students' area of research. All reading levels can be reached this way.

b. Books of all sort, comic to treatise: films of all sort, pure fun to documentary; short writings, journals, teen-magazines, newspapers, women's magazines; pamphlets, radio and television - all media should be considered because we are interested in what people read and listened to and what is the message? How is it received?

c. As wide range of these materials as possible should be planned, repetition avoided and individual reading, listening and viewing hablts consldered as much as possible.

d. A specific area within (c.) is the blography used as case history. These are to be considered in their context of history and the prevalling culture and not for purpose of generalization. Instead the biography serves as a tool for clarifying the difference between statistical information as a basis for generalizations and individual case histories as examples of, and sources of, Innovation and varlety of human experience. 
3. The classroom is considered an arena for the processing of material contributed by class members. Methods for this processing are Iisted.

a. Horton's "order and conflict theories of social problems as competing Ideologies" is useful to detect the intent of the writer. A preceeding section described this concept in essence as the Individual's decision-making process. Later it was shown how these processes inculcate differing psychologies and how they are realized in the contrasting sociologies appearing in Horton's paradigm.

b. Varlations of the two processes may be found.

c. Teachers may relate materfal to their own field.

d. Teachers may relate materlal to fellow teacher's fleld seeking potential areas of cooperation for integrated teaching programs.

4. Classroom interaction formulations:

a. Small groups with a maximum of fifteen students are important to the working of this program.

b. Coeducational classes are a must for contrast of opinton and breadth of human resource.

c. Participant structuring of time 1 imit to debate and individual expression of opinion will assure fellowshtp and full use of class time.

d. In-service teachers should at every class meeting bear a very easily read identification if they are from different schools.

e. Seating at no time should be rigid.

f. Role-play is a useful technique. Activities can be varied 
through the use of panels, concentric circle discussion, dialogue and student discussion leaders.

g. Special attention is given to the most profitable use of films giving in-service teachers ample opportunity to study the films and practice handing their discussion.

Every effort should be made to establish an easy atmosphere at the first class meeting.

INTRODUCTION AND PROGRAM OUTLINE

\section{Introduction}

A series of ten suggested topics for at least as many sessions, plus accompanying resource materials, form the core of the in-service program. The basic intent of the design is to include all essential topics from both the physical and soclal sciences. Teachers will, of course, find many other excellent materlals to be useful.

Topics are chosen in order to first lead the teacher-in-service toward an analytical approach to famlly life materials. Further, teachers are encouraged to seek out frames of reference used in wrttings on human development. Through discussion teachers will become an active part of the material under study. Several of the sessions are concerned with pertinent aspects of the social institutions of family, religion, education and economics. In addition extensive consideration of physical aspects of human development and their soctal implications is given. Social change as it is related to the family and male and female roles is important. This emphasis is entirely in keeping with the soctal psychological frame of reference in which the entire study is placed. 
GENERAL READINGS

The general readings are intended to be used as basic sources of Information. Implementation of the shared readings concept would provide a wide resource for the class.

William Goode gives a brief but clear soclological approach to the general theoretical question of family life in his The Family, Englewood Cliffs, N. J.: Prentice-Hall, 1964.

Two recent books are intended as texts in studying the social aspects of marriage and family. Particularly strong on cross-cultural material and descriptions of family structure and change theories is, The Family in Social Context, by Gerald Leslie, New York: Oxford Unfversity Press, 1967. Somewhat less theoretical but placing more stress upon controversial issues of male-female interpersonal relationships is Richard Udry's, The Social Context of Marriage, New York: J.B. Lippincott, Co., 1966.

Willard Waller who died early in his career wrote the first modern text on the family from an interactional point of view. His book, The Family, A Dynamic Interpretation, was revised by Reuben Hill, New York: The Dryden Press, 1956.

Not entirely up to date but still a very useful general text is Clifford Kirkpatrick's, The Fomily as Process and Institution, New York: Ronald Press, 1955. He gives special attention to the changing role of women. A newer publication with less appreciation of the interactional point of view is Harold T. Christensen's Handbook of Marriage and the Family, Chicago: Rand McNally \& Co., 1964.

Collections of readings often contain writings by well-known 
Individuals noted for unique approaches to controversial questions. Two books of this sort for the area of family are Edwin M. Schur's The Fomily and the Sexual Revolution, Bloomington: Indiana University Press, 1964, and Marvin B. Sussman (ed.) Sourcebook in Marriage and the Fomily, Boston: Houghton Mifflin Co., 1963.

An indispensable reading for its historical Information has been written by Sidney Ditzion, Marriage, Morals and Sex in Amerioa, New York: Bookman Associates, 1953. At least one student in a famtly 1ife class should read this book in order to act as resource person for its extremely interesting material. Of particular quality is Ditzion's objective reporting of early American attempts at soclal action in the family life field.

It has been suggested that some students may be interested in reading blographical publications as individual case studies of human development. A composite of such studies is found in Victor Goertzel's Cradles of Eminence, Boston: L1ttle, Brown, 1962. Another by Anne Roe, The Making of a Scientist, New York: Dodd, Mead, 1952, is the psychologists'report of her biographical study of sixty-four scientists.

In order that a family life teacher stay appratsed of the field, subscribing to the following is essential:

SEICUS NEWSLETTER, 1855 Broadway, New York, N. Y., 10023. NEWSLETTER, Population Policy Panel of Hugh Moore Fund, 60 East 142 Street, New York, N. Y., 10017. POPULATION BULLETIN, published six tines a year by the Population Reference Bureau, Inc., 1755 Massachusettes Ave., N. W., Washington D. C., 20036. 
PUBLIC AFFAIRS Pamphlets, 381 Park Ave. South, Ner York, N. Y.,

10016. (Espectally good on population.)

PLANNED PARENTHOOD NEWS, 515 Madison Ave., New York, N. Y., 10022.

JOURNAL OF MARRIAGE AND THE FAMILY, The Council on Family Relations,

1219 University Ave. S. E., Minneapolis, Minn., 55414.

THE FAMILY COORDINATOR, The National Council on Family Relations,

1219 University Ave. S. E., Minneapolis, Minn., 55414.

Other sources of educational materials upon request are:

Maternity Center Association, 48 East 92nd St., New York, N.Y., 10028.

E. C. Brown Trust Foundation, 3170 S. W. 87 th Ave., Portland, Oregon, 97225.

American Medical Assoctation, 535 North Dearborn St., Chicago, I11., 60610 .

American Soctal Health Association, 1740 Broadway, New York, N.Y., 10019.

The Child Study Association of America, 9 East 89 St., New York, N. Y., 10028.

A general bibliography of publications for a communtty program "Attitudes In Sexuality", is available from the Departinent of liealth Education, University of Oregon, Eugene, Oregon, 97403. It 11sts only recent publications. Horton's paradigm could be profitably applied to any similar list. 
READINGS SECTIONED FOR IN-SERVICE EDUCATION OUTLINE

\section{Session 1}

Comparative Interpretations of Sclentific Method and Their Appllcation to the Social Sciences.

The purpose of the first session is to set an analytical pace for the program. Readings are selected to enable participants in an objective application of sclence as a tool working toward that goal.

Shared readings through group discussion may be utilized by the teachers. They will profit by exchange between the various fields represented in their group. The question, "How can I apply the tool of sclence to my teaching area?," must be answered by the Individual for himself.

A book available in paperback which will serve as a refresher for teachers who studied sociology not too recently is: Peter L. Berger, Invitation to Sociology: A Hlunanistio Perspective, New York: Doubleday, 1963. As the title implies, Berger's point of view coincides with that which this paper attempts. Another paperback which more exclusively emphasizes the scientific method for the social sciences is: George A. Lundberg, Can Science Save Us?, McKay, 1961. The age of this writing is no deterrent to its value to the course. Two other books written in a more philosophical vein are: J. Bronowski, Science and Human Values, New York: J. Messener, 1956; and Abraham Maslow, The Psychology of Science, New York: Harper \& Row, 1966.

An important aspect of any application of the scientific method, the soclology of knowledge, is explored by two well-known social 
sclentists. Robert Merton considers the existentlal bases of man's knowledge in "The Sociology of Knowledge" edited by Gurvitch and Moore and found In Twentieth Century Sociology, New York: The Philosophical Ltbrary, Inc., 1945 .

Karl Mannheim writes on the same subject in quite a different manner in Ideology and Utopia, New York: Harvest Books, 1959. Espectal1y good 1s Louis Wirth, preface and pages 67-83 and 269-275 where Mannhelm focuses on the difference between relativism and relationalism. These books are essential to the understanding of how man contributes to his environment.

other readings involving sclence and human values are:

Bruyn, The Human Pesspective in Sociology, forward by Blumer, pp. 111-vi.

Deutscher, "Words and Deeds: Social Sclence and Social Policy", in American Journal of Sociology, Vo1. LXXXI, May 1966, pp. $701-713$

Felgl and Brodbeck, (eds.), Readings in the PhiZosophy of Science. New York: Appleton-Century Crofts, Inc., 1953, pp. 3-.8; 8-18; $674-676 ; 766-778$.

Gouldner, "Ant1'Minotaur: The Wyth of a Value Free Soclology", Social Problems, Vo1. 9, Winter 1962, pp. 199-213. Moore, "Strategy in Social sclence", in Stein and V1dich, Sociology on Trial, pp. 66-95. 


\section{Session 2}

Detection of Frames of Reference Used in Writings on Human Development

Continuing the analytical approach to subject matter begun in the first session teachers are asked in this session to seek out frames of reference found in family life materials. In order to do this they wust first familiarize themselves with schools of social psychological thought likely to be utilized by family life writers. Through the reading recommended for this session the teacher w11 also gain knowledge of primary Interaction prerequisites to an Integrated self concept.

Concentric circle discussions may be used in addition to techniques already mentioned. Here small groups, five for example, pulled out of the total class, conducts a discussion within the circle of the remainder of the class. This variation gives an opportunity for both new discussion relationships and observation. Horton's dichotomy is useful here as described earlier.

The instrument for this session of the program and throughout where applicable is John Horton's "Order and Conflict Theorles of Social Problems as Competing Ideologies", American Joumal of Sociology, May 1966, Vo1. LXXI, 6.

Readings relating to personallty in sociological theory:

Helne, "The Problem of Personality in Sociological Theory", in Wepman and Heine, Concepts of Personality, pp. 385-409. Strauss, "Transformations in Identity", in Rose, Fiuman Behavior and Social Processes, Boston: Houghton Mifflin, 1962, pp. 63-85. 
Readings in interactiontsm are:

Cooley, Charles Horton, Human Nature and the Social Order, New

York: C. Scribner's Sons, 1922.

Foote, Nelson and Leonard S. Cottre11, Jr., Identity and Interpersonal Competance, Chicago: University of Chlcago Press, 1955 .

Lindesmith, Alfred, and Anselm Strauss, Social Psychology, rev. ed., New York: Holt, Rinehart and Winston, 1956.

Mead, George Lerbert, Mint, Self and Society, Chicago: The University of Chicago Press, 1934. (Excellent introduction by Charles Morris.)

Strauss, Anselm, ed., George Herbert Mead on Social Psychology, Chicago: The University of Chicago Press, 1964.

Blumer, "Society as Symbollc Interaction", In Rose, Human Behavior and Social Processes, Boston: Houghton Miffin, 1962.

Readings in structure-functionalism (classed as "order" perspective by Horton):

Devereux, "Parson's Sociological Theory", In Max Black, ed., The Social theories of Talcott Parsons, Englewood Cliffs, N. J.: Prentice Ha11, 1961, pp. 1-63.

Parsons, Talcott, Social Structure and Personality, New York: The Free Press, 1964.

Wrong, Dennis, "The Oversocialized Conception of Man", American Sociological Review, Apr11 1961, Vo1. 26, pp. 183-193. Introductory reading to psychoanalytic theorles of personality: Bruce, Paul, "Three Forces in Psychology and The1r: Fthical and 
Educational Implications", The Educational Fomm, March 1966, Vo1. 30, 3, pp. 277-285.

Readings in psychoanalyttc theories of personality:

Blum, Gerald s., Psychoanalytic Theories of Personality, New York:

McGraw-Hill Book Co., 1953.

Freud, Sigmund, Three Essays on the Theory of Sexuality, New York:

Bastc Books, 1962.

Bettelheim, Bruno, The Empty Fortress, New York: Free Press, 1967.

(A detailed account of infantile autism, his theory is

psychoanalytic but his treatment rests upon interactionism.)

Readings in criticism of psychoanalytic theorles of personality:

Beach, Frank A., "The Descent of Instinct", the Psychological

Review, 1955, Vo1. 62, pp. 401-10.

Chodoff, Paul, "A Critique of Freud's Theory of Infantile

Sexuality", American Journal of Psychiatry, Nov. 1966, Vol.

123,5, pp. $501-517$.

Mowrer, 0. H., Introduction in Glasser's, Reality Therapy: A New

Approach to Psychiatry, New York: Harper \& Row, 1966.

Readings in "Third Force" psychology:

Allport, Gordon, Becoming, New Haven: Yale UnIversity Press, 1965. May, Rollo, ed., Existential Psychology, New York: Random House, 1967.

Maslow, Abraham, Toward a Psychology of Being, Princeton, N. J.:

Van Nostrand, 1962.

Rogers, Car1, On Becoming a Person, Cambridge, Mass.: Riverside

Press, 1961. 
Readings in Human Communtcation are:

Buber, Martin, Between Man and Man, New York: The Macmillan Co., 1965.

Klapper, Joseph, The Effects of Mass Communication, New York: The Free Press, 1965.

Kluckhohn, Clyde, "Culture and Behavior", in Gardiner Lindzey, Handbook of Social Psychology, Vol. II, Cambridge, Mass.: Addison-Wesley Publishing Co., 1954.

McLuhan, Marshal1, Understanding Media: The Extensions of Man, New York: McGraw-H111 Book Co., 1964.

\section{Session 3}

\section{Comparison of Changing Family Patterns}

The comparative study of fantly patterns is intended to widen the teacher's world-view. Reading and discussing utopian family patterns, old and new as well, may bring heated debate. Horton's dichotomy may be applied to retain objectivity. At this point, if not earlier, participants will be able to begin working through some of their own feelings which may be a handicap to objectivity in the classroom. Divorce, for example, is just one of the social problems brought out by the readings.

Although basically structure-functional in his theory, William Goode leans toward interactionism in his more recent writing on the family. This is apparent when he refers to changlng family patterns as evidence of the famfly structure as a mediating factor in society. Orthodox structure-functionalism would identify family change as a break-down of the traditional institution. A basic reading on family 
pattern by Goode is, World Revolution and Family Patterns, London: Free Press of Glencoe, 1963. A reader of the latter sort is Ruth Anshen, ed., The Fomily: Its Function and Destiny, New York: Harper \& Brothers, Pub., 1949. An article which attempts a reconciliation of the problem by Jetse Sprey is "Famtly D1sorganization: Toward a Conceptual Clarification", in Journal of Marriage and the Family, November 1966 , Vo1. 28,4 .

Earlier writings suggesting family reforms are described in the book by Ditzion, already 11sted. In addition students will find the following of interest:

Lindsey, Ben, Companionate Marriage, New York: Bont and Liverwright, 1927.

Estlake, Allen, The Oneida Community, London: George Redway, 1900. Russe11, Bertrand, Marriage and Morals, New York: L1verwright Pub. Corp. , 1929.

Young, K., Isn't One Wife Enough?, New York: Holt, 1954.

Readings in debate of nuclear and kinship family pattern of contemporary society:

Wirth, Louls, "Urbanlsm as a Way of Life", American Journal of Sociology, July 1938, Vol. 44, pp. 1-24.

Parsons, Talcott and Robert Bales, Family, Socialization and the Inter-Action Process, Glencoe, I1l.: The Free Press, 1955, chapter 1 .

Sussman, Marvin and Lee Burchinal, "Kin Fam1ly Network: Unheralded Structure in Current Conceptualizations of Family Functioning", Marriage and Fomily Living, August 1962, Vo1. 24, pp. 231-240. 
Young, M1chael and Peter W111mott, Kinship and Fomily in East London, Glencoe, I11.: The Free Press, 1957.

Readings in speciflc contemporary family patterns are:

Bernard, Jessie, Marriage and Family Among Negroes, Engelwood

Cliffs, N. J.: Prentice-Ha11, 1966.

Calderone, Mary, "The Married Teenager", SIECUS reprint.

Calffornia, "The Teenage Parent, Early Marrlage and Childbearing", revised proceedings of sympostum, Summer 1964, University of

California at Davis. Dean of Extension, Administration Ha11, University of California at Davis California, 95616.

Cuber, John and Peggy Harroff, The Significant Americans, New York: Appleton-Century, 1965.

Goode, W11llam, Women in Divorce, New York: Free Press, 1965.

Hunt, Morton, The World of the Formerly Married, New York: McGrawHi11, 1966.

Makarenko, A. S., The Collective Fomily: A Handbook for Russian Earents, New York: Doubleday, 1966.

Mead, Margaret, "Marriage in Two Steps", Redbook, July 1966, Vol. 127,3 .

Spiro, Melford, Kibbutz: Venture in Utopia, New York: Schocken Books, 1967.

V1ncent, Clark, "Unmarried Mothers", SIECUS reprint.

Readings in contemporary utoplas are:

Huxley, Aldous, Island, New York: Harper and Brothers, 1962.

Skinner, B. F., Walden Two, New York: MacmI1lan, 1948. 


\section{$\underline{\text { Session } 4}$}

\section{Application of the Sclentific Humanistic Perspective to Soclal Change Theories}

The difficult question of social change and contemporary trends in family patterns grows out of the topics included in the readings for this session.

In his last chapter of The Fomily, previously listed, Willian Goode comes to the conclusion that we have no satisfactory theory of social change. He chides other writers for calling technological invention soctal change. Actually, he says, this is not a theory of change but change itself. He might have gone on to say that all of social Interaction in its bit by bit bullding process is social change.

Readings considering vartous aspects of soctal change are:

Allen, Francis, et al, Technology and Social Change, New York: Appleton-Century--Crofts, Inc., 1957.

Childe, Gordon, Man Makes Himself, New York: World Literature, Inc, 1951.

Forbes, R. J., Man the Maker, New York: Abelard-Schurnan Ltd., 1958.

Mills, c. Wright, The Power Elite, New York: Oxford University Press, 1959, Chapter 13.

Rosenberg, Bernard, ed., Analysis of Contemporary Society, New York: Thomas Y. Crowell Co., 1966.

Vincent, Clark, "Mental Health and the Fam1ly", Joumal of Marmiage and the Fomily, February 1967, Vo1. 29, 1. 


\section{Session 5}

Mate Selection, Human Reproduction Potential and Related Topics

It is quite possible that many groups w111 devote more than one tenth of the in-service program tine to this session. Research conducted in relation to this study, and the professional 11terature consulted, show teachers lack skill and knowledge in this area. Therefore, the additional time would be fustified. A great deal of time is required for films and their discussion. The most constructive use of the participants' time requires their conducting these sessions while the leader performs as moderator. The result is a dialogue-centered classroom where teachers have an opportunity to become aware of their own feelings. Role-play where teachers assume student roles may cause a realistic turn in the teacher's abllity to verbalize newly gained knowledge.

\section{Readings in Human Reproduction are:}

Lader, Lawrence, Abortion, New York: Bobbs-Merr111 Co., 1966. Montagu, Ashley, Life Before Birth, New York: New American Library, 1965.

Stiller, Richard, ed., IZlustrated Sex Dictionary, New York: Heath Publications, 1966.

Films, human reproduction, avallable from State Film Library are:

Human and Animal Beginnings

Boy to Man

Gipl to Woman

Human Growth 
Parent to Child About Ses

Human Reproduction

A Normal Birth (See Oregon State Film Library catalogue, 1967.)

Illustrative materials (Maternity Center Association, New York):

Birth Atzas

Organs of Iluman Reproduction

Readings in sexuality are:

Hettlinger, Richard, Living With Sex, New York: The Seabury Press, 1966.

Kirkenda11, Premarital Intercourse and Interpersonal ReZationships, New York: Matr1x House, 1966.

Masters, William and VIrginia Johnson, Iluman Sexual Response, Boston: Little, Brown and Co., 1966.

Pike, James, Teen-Agers and Sex, Engelwood Cliffs, N. J.: Prentice Hall, Inc., 1965.

Re1k, Theodore, Psychology of Sex Relations, New York: Grove Press, 1945.

Sex education pamphlets and reprints are:

SIECUS (discussion guides)

1. "Sex Education Outline"

2. "Homosexuality"

3. "Masturbation"

SIECUS (reprints)

Llef, Harold, "Masters-Johnson Research - An Evaluation".

Rub1n, I., "Transitions in Sex Values - Implications for the Education of Adolescents". 
Public Affairs Pamphlets

K1rkendal1, Lester, "Sex and Our Society".

Friends book Store, 304 Arch St., Philadelphia, Penn.,

"Towards A Quaker View of Sex", A. Heron, ed., 1964.

Swedish Information Service, 8 East 69th St., New York, 10021.

"Society and Sex 1n Sweden".

Readings in mate selection are:

Bolton, Charles D., "Mate Selection as the Development of a Relationship", Mariage and Family Living, August 1961, Vo1. XXIII, pp. 234-240.

Trost, Jan, "Some Data on Mate Selection"; Winch, Robert, "Another Look at the Theory of Complementary Needs in Mate Selection", Joumal of Marriage and the Fanily, November, 1967, Vol. 29, pp. $730-762$.

Winch, Robert, Mate Selection, New York: Harper, 1958.

Readings in family planning are:

Guttmacher, Alan, Planning Your Family, New York: The Macmillan Co., 1964.

Rainwater, Lee, Fomily Design, Chicago: Aldine Pub. Co., 1965.

Planned Parenthood Association pamphlets are:

"Methods of Contraception in the U.S.", 1965.

"The Control of Fertility"

"The Churches Speak up on Birth Control"

(Film strips and demonstration materlals are also available.)

Readings In Population are:

Spengler, Joseph and Otis Duncan, Demographic Analysis, Glencoe, I11.: The Free Press, 1956. 
Thomlinson, Population Dynomics, New York: Random House, 1965. Other family planning and population materlals are:

Public Affalrs Pamphlets:

"This Crowded World", 306.

"A New Look at This Crowded Worid", 393.

Hugh Moore Fund Population Polfcy Panel:

"The Population Bomb"

Population Bulletin, Population Reference Bureau, Inc.

(Ask for listing of back issues; Vol. XXI, 2; Vol. XXII, 4, 5, are especially good issues.)

\section{Session 6}

Male and Female, Social Sexual Developrent

Much of the material discussed in previous sessions will apply to this topic. An additional technique has teachers relate the later experiences of subjects from biographical readings to their possible perceived male or female role as a child. Since biographical readings are especially popular with primary and secondary students, teachers may find this perspective helpful. Special emphasis upon changing definitions of male and female roles is essentla1. The concept of mutual responstbility of the sexes for interpersonal relationships is desirable. However, readings have been chosen to offer a wide selection of male-femalè role perspectives. Horton's dichotomy can be applied as in most other sessions.

Readings intended to place equal emphasis upon the sexes are:

Calderone, Mary, "The Development of Healthy Sexual1ty". (Enphasis 
upon non-verbal learning and sexualtty development as a lifelong process.) SIECUS reprint.

Colley, Thomas, "The Nature and Origins of Psychological Sexual Identity", Psychological Review, 1959, 66, pp. 165-177.

Lynn, David, "The Process of Learning Parental and Sex-Role Identification", Joumat of Marriage and the Fanily, November 1966, Vo1. 28,4 .

Mead, Margaret, Male and Eemale, Morrow, 1949.

Kinsey, A. C., et al, Senual Behavior in the Human Female, Saunders, 1953, contains comparisons with the results reported in Sexual Behavior in the Human Male, 1948, and useful references to other studies.

Readings with special reference to the human male are:

Brenton, The American MaZe, New York: Coward-McCann, Inc., 1966. Ferguson, Charles, The Male Attitude, Boston: Little, Brown \& Co., 1966.

Readings with spectal reference to the human female are:

Beauvoir, Simone, The Second Sex, New York: Knopf, 1952.

Borgese, E11zabeth, Ascent of Woman, New York: George Braziller, 1963.

Deutsch, Helene, The Psychology of Women, New. York: Grune and Stratton, 1944.

Hefner, Hugh, Play Boy Philosophy, Chtcago: Play Boy Magazine, 1963.

Hunt, Morton, Her Infinite Variety, New York: Harper \& Row Pub., 1962. 
Langdon-Davies, John, A Short History of Women, New York: Viking Press, 1927.

Le Cappellanus, The Art of Courtly Love, New York: Frederick Ungar Pub. Co., 1957.

Seltman, Women In Antiquity, New York: St. Martin's Press, 1955.

Educational tapes, Audio Arts, 2828 S. W. Front Ave., Portland, Oregon, 97201 :

"About Men"
"About Girls"
"Questions Most Asked by Girls"
"Questions Most Asked by Boys" (about themselves)

Session 7

The Phenomena of Adolescence

A panel of adolescent students can be utilized here. One suggestion has students appearing on the panel and the teachers read the same material before the session.

Topics for discussion with the panel will be dependent upon the particular situation. There are readings, however, which will be of help in setting up the discussion:

"Developing Open Communication About Sex with Youth", Deryck Calderwood and Leila den Beste, and,

"Using a Student Panel in Teacher Education on Sex Standards", Lester Kirkenda11, both in Journal of ifarriage and Family, November, 1966, Vol. 28, 4. 
Read1ngs, generally pertinent to the subject are:

Friedenberg, Edgar, Coming of Age in America, New York: Random House, 1.965 .

Goodman, Paul, Growing up Absurd, New York: Random House, 1960. Havighurst, Robert, and Hilda Taba, Adolescent Character and

Pensonality, New York: John Wiley \& Sons, Inc., 1949.

Mead, Margaret, Coming of Age in Scomoa, New York: Willlam Morrow $\$$ Co., Inc., 1949.

Miller, Warren, The Cool World, New York: Little, Brown \& Co., 1964.

Simmons, J. I. and Barry Winograd, Its Happening, Santa Barbara: Marc-Laird Publications, 1967.

Filng are:

Phoebe, Story of Premarital Pregnancy, McGraw-Hill.

You're No Good, (A fatherless and confused 18 yearmold school dropout), McGraw-Hill.

\section{Session 8}

Relating Religion and Family Life

Talking with ministers of various religlous faiths is the most important activity of this session. The purpose of these talks is to discover how the ministers believe their faith regards important aspects of family life. Contraception, divorce, abortion and the role of women in the narriage relationship are a few of the topics the class may want to explore.

Some of the readings previously listed contain material of 
relevance to this session. These include Hettlinger, Pike, Buber and Lundberg, chapters five and six. Planned Parenthood's pamphlet, "The Churches Speak Up on Birth Control", way also be used again for reference.

Readings relating to religion and the family are:

Genne, William, "The Churches and Sexuality", SIECUS NEWSLETTER, Fall 1960, Vol. 2, 3.

Glock, Charles and Rodney Stark, Religion and Society in Tension, Chicago: Rand McNaIly \& Co., 1965. Chapter 2 (dimensions of 'Religiosity') and Chapter 4 (application of Dtmensions to the question of religious revival in Arerica). Glock, p. 263, makes a very Interesting reference to Feigl, p. 16, see session 1 references.

Greater Portland Counc11 of Churches, "Young People Downtown", Portland, Oregon: Fall 1963. Doctrines of downtown churches are spelled out.

Herberg, Will, Protestant, Catholic, Jew, rev. ed., New York: Doubleday, 1960. Chapters 1-4. The author is concerned with the "melting pot" aspect of Americanssociety. He believes this country is at once becoming both more secular and more "religious".

James, William, Varieties of Religious Experience, New York: Modern Ltbrary, 1929.

Maslow, Abraham. ReZigions, Values, and Peak-Experiences, Columbus: OhIo State University Press, 1964. The author belleves his concept of "peak-experience" parallels religlous experience. 
Novak, Michael, ed., The Experience of Marriage, New York: Macmillan Co., 1964. Couples write essays of experience of Catholic marriage revealing today's problems of Catholic sexuality.

Rock, John, The Time Fas Come, New York: Knopf, 1963. A Catholic doctor's proposal to end the battle over birth control in his church.

Robinson, John, Honest to God, Philadelphia: The Westminister Press, 1963. The author proposes new images for cod and Jesus for contemporary Christianity.

Vincent, Clark, "Interfaith Marriage: Problen or Symptom?", In California, Religion and the Face of America, The University of California, 1958. The author believes the marital "I-Thou" relationshlp is often hampered by the " $I t$ " in the form of institutional loyalty. He proposes that thfs may be a fault of the church rather than the marriage.

White, A. D., A History of the Warfare of Science with Theology in Christendom, New York: Dover, 1960.

\section{Session 9}

Reviewing Education and the American Family

Despite the institutionalization of education, the child through prinary relationships in the home setting is deeply involved there in a most important part of his education. The suggested readings may offer at least two categories of thought and discussion to the class: 1 . How does this aspect of education affect the child outside the home, though 
that effect is then brought home? and 2 . How does this aspect of education relate to parent-child relationships, especially the parent as a teacher?

Readings previously 1isted which contain important sections relating to education are: Buber, pp. 83-117; Feigl and Brodbeck, pp. 8-18; Lundberg, chapter 4; M111s, chapter 13; Simmons and Winograd, chapter 8 , and Wheelis in Rosenberg, pp. 1-38.

Readings in education and the American family are:

Bruner, Jerome, Towards a Theory of Instruction, Harvard University: Belknap Press, 1966.

Dreikers, Rudolf, Psychology in the Classroom, New York: Harper \& Row, pub., 1957.

Fuller, Buckminster, Education Automation, Carbondale, I11.: Southern I111nois University Press, 1961.

Gagnon, John, "Sexuality and Sexual Learning in the Child", SIECUS reprint.

Gordon, Ira J., Intellectual Stimulation of Infants and Toddlers, Gainesville, Florida: University of Florida, 1967.

Spiel, Oskar, Discipline Without Punishment, London: Faber and Faber, 1962.

Kaufman, Bel, Up the Down Staircase, Engelwood Cliffs, N. J.: Prentice-Ha11, 1964.

\section{$\underline{\text { Session } 10}$}

Economic Factors, Stratification, Class Position and Family Varlables

Goode's tentative list of elghteen variables for scrutiny of the 
family from an economic point of view can serve as a basis for discussion in this session. The variables are found in The Fomity, pp. 81-82. Readings in general problems of economic processes are:

Galbralth, J. K., American Capitalism, Boston: Houghton Miffin, 1956. Also his Affluent Society.

M111s, C. Wright, The Power Elite, New York: Oxford University Press, 1959.

Readings relating to specific income groups are:

Bernard, Jessie, "Marital Stab1lity and Patterns of Status Variables", Joumal of Marriage and the Fomily, November 1966. Vo1. 28,4 .

Cuber, John, The Significant Americans, New York: AppletonCentury, 1965.

Harrington, Michael, The Other American, Baltimore, Md.: Penguin Books, 1965.

Rainwater, Lee, And the Poor Get Children, Ch1cago: Quadrangle Books, 1960.

U. S. Department of Health, Education and Welfare, "Low-Income Life-Styles", Publication No. 14, 1966.

Readings in Negro family life are:

Bernard, Jessle, Marriage and Family Among Negroes, Englewood Cliffs, N. J.: Prentice Hall, 1966.

Frazier, Frank11n, The Negro Fomily In the United States, rev. ed., ChIcago: The Untverstty of Chicago Press, 1966.

Kvaraceus, W111lam, et. al, Negro Self Concept, New York: McGraw$\mathrm{H} 111,1965$. 
Lincoln, Eric, "The Absent Father Haunts the Negro Family", New York Times Magazine, November 28, 1965.

Silberman, Charles, Crises in Black and White, New York: Random House, 1964.

\section{CONCLUSION TO THE IN-SERVICE PROGRAM}

The lively interest in family life education being show by young people and many of their parents and teachers may be offset by another factor. The very diversity of concept which the above program stresses may result in an unwieldy difference in goals.

Communication difficulties are bound to persist. Dispartty of ages and experienced rates of cultural change throughout the IIfe span are unavoldable. The resulting variety of meanings and selectivity of perception can at least be modified through discussion.

What nlay be an unattainable prescription for the practice of reason appears in the family life program. Should use of the program be blocked by fears of the new and desire to retain the old, reason w111 have already failed. The search for certainty can also act as a deterrent to reason. Absolute guides to human interaction are no nore obtainable by reason than by non-reason.

Today young people acquire much general information but are frequently thrown on their own resources for decision-making. This breadth of knowledge plus their extensive recreational experience is offset by a lack of opportunity to participate at depth in the ongoing housekeeping sort of business of the adult world. Activities for youth tend to be at a pseudo, or not quite essent1al, level. (Recall Vermes" 
suggestion that young people be kept busy with such projects as the winning of Olympic medals.)

Critics of decision-making by youth via the existential ethic may be very correct in saylng young people are not ready for $1 t$. This suggested program is offered as a tool in a complex situation demanding a pluralistic approach. Everyday meaningful participation in human events that matter to the operation of soclety has no substitute. Unless his experiential level is adequate, an Individual may be more comfortable while being guided by tradition rather than reason. As mentioned earlfer, the actual decision made in a particular situation may be the same regardless of the means used for reaching it. It is the Individual with neither firm traditional commitments or the strength of an existential ethic who may be most touched by the proposed family life program. Communication theory, although tentative, points to this supposition. For this reason our stress upon the objective presentation of the program materlal is of great importance.

Two final points demand attention. The first concerns the teacher. objectivity is extremely difficult. Whenever it is impossible the teacher is called upon to identify his subjectivity as being just that and to seek out diversity in the classroom as a counter force.

The second point is closely related and encouraging. There is an emergence of rational potential, Bruner says, which is not found in hormonal adolescents in technically less mature societles. Something very spectal happens when language becomes increasingly important as a medium of thought. "It is evidenced by an ablity to consider propositions rather than objects; concepts become more exclusively hierarchical 
in structure; alternate possiblifties can be handled in a combinatorial fashion", according to Bruner. 43

It is this emerging process of reflection which the foregoing plan for famlly life education would entertain. 
THESIS SUMMARY AND CONCLUSIONS

Research of conditions in a specific metropolitan area and opinions from the professional 1iterature have been presented to support the stated extstence of a pedagogical problem. That problem has been defined as teacher inadequacy to the task of family life education in primary and secondary schools.

Fantly life education for the purpose of this study is defined as, "classroom education deallng with both the biological and sociological aspects of the Individual's development which particularly Involve awareness of one's present and potential family interaction and its relationshtp to patterns of the ongoing 1ffe process." The description was selected in order to place the problem in an ongoing, social psychological, frame of reference.

Investigation shows that teachers are inadequate to the family life teaching task, first, because they lack the necessary knowledge which. must be drawn from both the physical and the social sciences. Secondly, adults frequently find they experience fears and doubts which inhtbit their freedom to discuss toples pertaining to sex. Sex education has been found a necessary part of family life education. In order to modify the deterrents to teacher adequacy an in-service program of teacher education is proposed. The program is realized through a cooperative plan to Involve teachers in a maximum information and experiential environment.

The content of family life education includes both blological and 
sociological aspects. Further, it has been shown, the ability to communfcate applicable parts of both soclal and physical sciences is as important as its knowledge. Although subject matter is extremely limportant, its implenentation is equally so. If the program teacher is knowledgeable, and possesses student rapport, the remaining skI1I development task is accomplished only through class involvement of each teacher-1n-service.

The study places an emphasis upon comnunication because such skills have been shown to be very important to the success of the family life teacher. Further, it is revealed, the communication process itself is basic to human interaction and therefore to development. This interpretation of the human process points to a consideration of the family as a social institution in its interaction with other ongoing social patterns. In this frame of reference the in-service program provides an opportunity for an analytic approach to family life materials.

Only through actual discussion can the fullest opportunity be given teachers to become aware of their own attitudes relevant to teaching family Iffe. Again, only through actually discussing difficult topics can teachers overcome the hesitancy to meet frank statenents and inquiries in their classrooms. Because there is much uncoordinated material for family life education it is suggested that teachers-inservice each read different materials and share them through discussion in the proposed ten program sessions.

The program teacher should be acquainted with all possible materials. When diversity of optnion and emotionally based discussion threaten thoughtful participation Horton's dichotony may be applied as a 
moderator. Or, the dichotomy is used as an initial analytical tool which may also serve as a discussion catalyst. To be more exact, the in-service program teacher must be skilled and knowledgeable in addition to attaining excellent rapport with teachers-tn-service. Through this rapport and openness of discussion, it is hoped that the teacher-inservice may in turn carry the accompanylng sk111 and knowledge to the classroom.

Lack of ski11 and knowledge has been said to describe the pedagogical problem of teacher inadequacy to the family life education task. The proposed in-service program contains elements of both social and physical sciences pertinent to family life. It is accompanied by teaching techniques intended to encourage teachers to communicate, and thus become more skilled and aware of, related attitudes which may hamper their teaching. Through implementation of such a program the deterrents to teacher adequacy to the famlly life education task may be modified. The interested primary or secondary teacher is then fxeed from concern over dealing effectively with his own feelings - freed to become a part of and make the most of the teachable moments which his zest and confidence thay inspire. 
BJBLIOGRAPHY

Avery, Curtis E. and Margle R. Lee. "Family Life Education: Its Philosophy and Purpose", The Fcanily Life Coordinator, Apr11, 1964, vol. 13, no. 2 .

Berger, Peter L.: Invitation to Sociology: A Humanistic Perspective. Garden City: Doubleday \& Co., 1963.

Blological Sclences Curriculum study. Biological Science, An Inquimy Into Life. New York: Harcourt, Brace and World Inc., 1963.

Brandwein, Paul. The World of Living Things. New York: Harcourt, Brace and World, Inc., 1964.

Bruner, Jerome S. "Education as Soctal Invention", The Saturday Review, February 19, 1966, vol. 49, no. 8 .

Bruner, Jerome S. The Process of Education. New York: Random House, 1960.

Freud, Sigmund. Civilizationand its Discontents. London: Hogarth Press, 1930.

Freud, Sigmund, Three Essays on the Theory of Sexuality. New York: Basic Books, 1962.

Goodman, Paul. Growing Up Absurd. New York: Random House, 1960.

Hettlinger, Richard F. Living With Sex. New York: The Seabury Press, 1966.

Horton, John. "Order and Conflict Theories of Social Problems as Competing Ideologies", The American Joumal of Sociology, May 6, vo1. 71 , no. 6 .

Kirkenda11, Lester A. Premarital Intercourse and Interpersonal ReZationshipo. New York: Matrix House, Ltd., 1966.

Klapper, Joseph T. The Effects of Mass Comminioation. New York: The Free Press, 1965.

Lindesmith, Alfred R., and Anselm L. Strauss. Social Paychology, rev. ed., New York: Ho1t, Rinehard and Winston, 1956.

Maslow, Abraham H. Religions, Values, and Peak-Experiences. Columbus: Ohio State University Press, 1964.

Masters, William H. and VIrgInia E. Johnson. IHuman Sexual Response. Boston: Little, Brown and Co., 1966. 
May, Rollo (ed.). Existential Psychology. New York: Random House, 1967.

Multnomah County Medical Society. The Bulletin, vol. 22, no. 3, March, 1967 ; vol. 23 , no. 3, March, 1968.

Parsons, Talcott. Social Stmuctures and Personality. London: The Free Press, 1964.

P1ke, James. Teen-Agers and Sex. Englewood Cliffs, N. J,: Prentice Hall, 1965.

Rainwater, Lee. Fomily Design. Chlcago: Aldine Publishing Co., 1965.

Rogers, Car1 R. On Becoming a Person. Cambridge, Mass.: Riverside Press, 1961.

SIECUS NEwsletter. Winter, 1968, vo1. 3, no. 4.

Somerville, Rose M. "The Relationship Between Family Life Education and Sex Education", Joumal of Marriage and the Fomily, May, 1967, vol. 29 , no. 2 .

Strauss, Anselm (ed.). George Herbert Mead on Social Psychology. Chicago: The University of Chicago Press, 1964.

Vander Zanden, James W. American Minority ReZations. New York: The Ronald Press Company, 1963.

Vermes, Hal and Jean. Helping Youth Avoid Four Great Dangers. New York: Association Press, 1965.

Watts, Alan. Nature, Man and Woman. New York: Pantheon Press, 1966.

Znanleck1, Florian. Cultural Sciences, Their Origin and Development. Urbana: Unfversity of Illinois Press, 1963. 
APPENDIX A

SEX EDUCATION AND INFORMATION COUNCIL OF THE UNITED STATES

\title{
THE SIECUS PURPOSE
}

To establish man's semulity as a health entity: to identify the spectal characteristics that distingulsh it from, yet relate it to, human reproduction; to dignify it by openness of approach, study and scientific research designed to lead towards 1 ts understanding and 1 ts freedom from exploitation; to give leadership to professionals and to society, to the end that human beings may be aided towards responstble use of the sexual faculty and towards assimilation of sex into their Individual life patterns as a creative and re-creative force.

\section{OFFICERS DF SIECUS}

\author{
President . . . . . Lester L. Doniger, Publisher, Manhasset, - \\ New York \\ Vice Presidents..... Jessie Bernard, Ph.D., Research \\ Professor, Honoris Causa, Pennsyl- \\ vania State University, University \\ Park, Pennsylvania \\ Harold I. Lief, M.D., Professor of \\ Psychiatry, Division of Family \\ Study, University of Pennsylvania \\ School of Medicine, Philadelphia, Pa. \\ J. Noel Macy, Washington, D.C. \\ Secretary . . . . Father George Hagmaler, C.S.P., Ed.D., \\ Associate Director, Paulist \\ Inst1tute for Religlous Research, \\ New York, N. Y. \\ Treasurer ....... Isadore Rubin, Ph.D., Editor, Sexology \\ Magazine, New York, N. Y.
}


Irmediate Past President . . David R. Mace, Ph.D., Professor of Family Soclology, Bownan Gray School of Medicine, WinstonSalem, N. C.

Executive Director . . . Mary S. Calderone, M.D., M.P.H. 
APPENDTX B

OREGON'S SEX EDUCATION PROGRAM - STATE DEPARTMENT OF EDUCATION

Division of Instruction - Special Consultant Services Section

\section{BACKGROUND}

Many requests for Information about Oregon's program of sex education in the schools are recelved by both the state Department of Education and the E. C. Brown Trust. These numerous requests evidently spring from Oregon's reputation for leadership in sex education and referrals by many professional people throughout the nation who are asked by communftles and schools for counsel in setting up school sex education programs. Oregon's reputation and philosophy respecting sex education are linked with a fairly complicated history which is set forth briefly here so that those who seek information may judge whether or not Oregon's experlences may be helpful to them.

First, the E. C. Brown Trust must be explained. This Trust was created in 1939 under terms of the will of Dr. Ellts C. Brown of Portland, who left the bulk of a considerable fortune for the establishment of an educational foundation devoted exclusively to sex education. Administrator of the fund is the president of the University of Oregon: the director is and always has been a member of the University's faculty. From the begfining, the Trust and the State Department of Education have worked together closely though informally.

In 1945 both the Trust and the Department of Education were interested in the passage of a state law requf.ring that health and 
physical education be taught in all Oregon elementary and secondary schools at all grade levels. The law was passed and its intent was Implemented in part by publication of a state health course of study entitled "Health Guide Units for Oregon Teachers, Grades 7-12." This course of study was prepared by Howard S. Hoyman, then Professor of Health Education, University of Oregon. It was published by the E. C. Brown Trust and distributed through the University's cooperative book store. In this program sex education was provided for various grade levels in connection with units of instruction on functions of the human body and communicable diseases. It was this combination of circumstances that led to the assumption by many that sex education was required in Oregon schools by law.

In 1949 the E. C. Brown Trust sponsored production of the film Human Growth, a pioneering effort in both audiovisual instruction and sex education. The film imnediately attracted widespread attention and was publicized in many national periodicals and newspapers. Some of these, on the basis of the health education law mentioned above, asserted that sex education was compulsory in oregon. Actually, the law Itself made no reference to sex education, although the eleven areas which are required in the health education progran are definitely defined and include many elements on sex education.

\section{GENERAL STATEMENT}

In keeping with the Oregon philosophy, sex education is conducted through regular health classes. There are areas outlined in the health instruction handbooks for Oregon schools which lend themselves readily 
to material of this nature. Teachers are encouraged to take advantage of the many opportunities afforded in these health unfts for including

fanily living, mental health, and moral and spiritual values where this Information would naturally appear. Each school is expected to emphasize this instruction according to the ability of the teacher and needs of the group. 
APPENDIX C

"LOVE IN CONTEMPORARY SOCIETY"

A Three-Day Working Conference - February $16-17-18,1965$

(An Activity of the Division of Continuing Education of the Oregon State System of Higher Education)

PART I - IMAGES OF LOVE IN CONTEMPORARY SOCIETY

\section{First Session:}

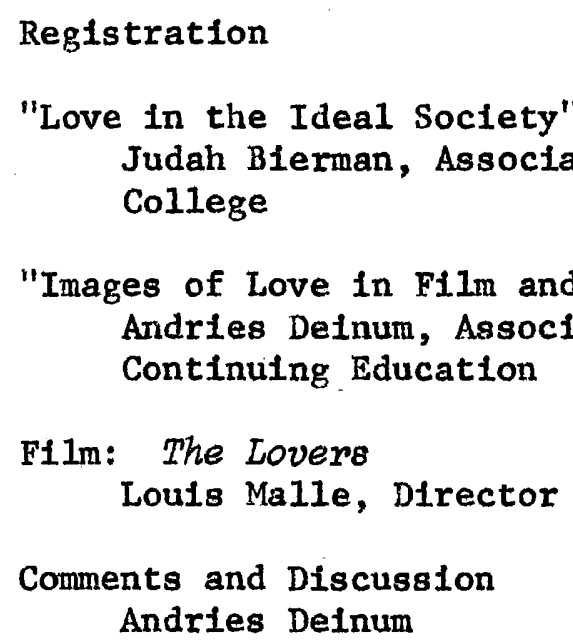

\section{Second Session:}

"The Rise \& Fall of Love in Public Media"

Dr. Peter Raible, Minister, University Unitarian Church, Seattle, Washington

Comment

Dr. James Breedlove; Associate Professor of Social Work, Portland State College

"Cultural \& Social Origins of Love Images"

Dr. Roy Rodgers, Assistant Professor of Soclology, University of Oregon 
Comment

George Saslow, M.D., Chaj.rman, Department of Psychlatry, University of Oregon Medical School

Sma11 Group Discussions

Kenneth Cunningham, Assistant Professor of Sociology, PSC Morris Weltman, Assoclate Professor of Psychology, PSC Joseph F. Jones, Assistant Professor of Sociology, PSC Nona Glazer, Assistant Professor of Soclology, PSC Jarvis M. Finley, Assistant Professor of Sociology, PSC Patrick J. McGillivray, Assistant Professor of Sociology, PSC Clyde Pope, Research Soclologist, Portland Comnunity Council

PART II - CONTEMPORARY PROBLEMS

\section{Third Session:}

Chatrman, Dr. Gordon Hearn, Director, School of Soctal Bork, PSC

"Love In the Abundant and Deprived Societies"

Mr. Michael Harrington, Free Lance Writer, Author of The Other America

Conment

Frederick Chino, Assistant Professor of Sociology, PSC

General Discussion with questions from the floor

\section{Fourth Session:}

Chairman, Dr. Lester A. Kirkenda11, Professor of Family Life, Oregon State University

"Procreation, Pleasure and the Pill"

Alan Guttmacher, M.D., President, Planned Parenthood - World

population

Comment

Paul Blachly, M.D., Assistant Professor of Psychiatry, Un1versity of Oregon Medical School.

Comment

Dr. Lester A. Kirkenda11

General Discussion with questions from the floor 
PART III - PROJECTS AND PROPOSALS TOR TIE FUTURE

\section{Fifth Session:}

Conference Banquet

Chalrman, Dr. Curt1s E. Avery, Director, E. C. Brown Trust

"Knowledge and Social Change"

Dr. Harry J. Alpert, Dean of Faculties, University of Dregon

\section{S1xth Session:}

Pane1 Discussion: "What Needs to be Done?"

Chaiman, Curtis E. Avery

Panelists: Alan Guttmacher, M.D., Mlchael Harrington, Lester Kirkendal1, Peter Raible, Roy Rodgers 
APPENDIX D

Invitationa1

"SEX EDUCATION GUIDELINES IN A MODERN SOCIETY"

Thursday, October 27, 1966 - Portland State College

Sponsored by:

Multnomah County Medical Society, Portland Publfc Schools, Portland State College

Registration - View Exhibits - Coffee Hour

Opening Session

Speaker; Harold I. Lief, M.D. "Some Problems \& Issues in Sex Education"

Intermission - View Exhibits - Coffee Break

Smal1 Discussion Groups

1. Instruction \& Guldance in Emerging Sexuality: Pre-Adolescent Emerging Sexuality

2. Instruction \& Guldance In Emerging Sexuality: Counseling Adolescents for Sexuality

3. Foundations for Modern Sex Ethics

4. The Family Role in Education for Sexuality

Informal Luncheon (no speaker) - View Exhtbits

Four 15-minute Presentations - Four Question-and-Answer periods

1. Sociological Aspects (Lester A. Kirkenda11, Ph.D.)

2. School Programs (Miss Helen Manley)

3. Activities of the E. C. Brown Trust (Curtis E. Avery)

4. Role of the Clergy (The Rev. Jack H. StIpe, ACSW)

Intermission - V1ew Exhibits - Coffee Break 
Panel Discussion: "Sex Education Guidelines"

Moderator: Dr. Harold I. Lief

Panelists: Dr. Lester A. Kirkenda11, Miss Felen Manley, Mr. Curtis E. Avery, Father Jack H. Stipe

Adjournment 
APPENDIX E

COP Y

LONGVIEW PUBIIC SCHOOLS

Longview, Washington

February 28, 1967

Mrs. Helen Running

1951 N. E. 142

Portland, Oregon 97230

Dear Mrs. Running:

You may be disappointed in the kind of information I am providing you on our Fanfly Life education program but the following is about as good a description of our situation as I can give you.

In the late 1940's as a high school princlpal I became concerned with the attitude of people in the conmunity toward high school boys' and girls' moral standards. In those years about the same situation existed as is common in many communitieg scattered over our country at the present time. I saw at that time, as many people are doing now, that there was a great need for sone agency to make a leading contribution to the development of family living education and all of its ramifications including sex education. Because of my concern and lack of knowledge of where to go I sought and found the opportunity to attend a s1x weeks institute in family living education at the University of California at Berkeley. Through that institute I became imbued with many of the ideas about sex education that $\mathrm{Dr}$. Calderone is presenting so well. Upon my return to the community I spent a busy year giving courses to groups of parents organized through Parent Teacher Associations and the adult education prograin of the schools, talking to faculty members in our schools and helping in any way I could to encourage teachers to start helpling parents by giving some instruction toward fanily living education and ses education fn our schools. The ldea took hold in a rather spasmodic way as you would expect, depending upon teachers' interest and confldence in their ability. At any rate we were able to start in a meager way giving some instruction that was acceptable to parents in our commity.

Before the above took place we had been showing flims on menstrua-tion to sixth grade girls. Boys were ignored. The showing of these films has continued and we have also found suitable films for fifth grade girls. With this fifth and sixth grade work as a basis we have developed a ten lesson unit of instruction for the seventh grade which involves reproduction as part of the study about the endocrine systems. As our systern has developed and as our instructors have changed I an of the opinion the development of attitudes toward sex is not very well done in this unit. 
LONGVIEW PUBLIC SCHOOLS

Page 2 of Copy

Over the period of years in the developing of this seventh grade unit and getting it well accepted by the community other developments have occurred in the senfor high school. Psychology was added to the curriculum as an elective for juntors and sentors. The ortginal instructor made an emphasis on understanding of one's self and included much about the effects of sexual development upon the emotional reactions of individuals and their societal relationships. This elective course has continued and probably affects from 50 to $60 \%$ of seniors before their graduation. At the same tine our blology instructors, of which the psychology teacher was one, became interested in making more of an emphasis upon human reproduction in thetr biological science course. This has continued also. Again I an inclined to believe that as the course developed we have gravitated toward mechanical processes rather than emotional reactions. Home Economics teachers have tried to include some general work about the family in the Home Economics courses but this has much distance to go to reach the goals in the true family living education program. Health teachers have given attention to sex education to some extent but boys much less than girls. In all these years our health teachers have not felt comfortable in doing very nuch about sex education in their program. I only point these out to emphasize to you that the spotty program of sex education in the Longview Schools has not developed a continuous course from which materials can be plicked to send as samples.

Because of the above situation on sex education we feel fortunate to have a few people in our community become imbued with the spirit they would like to do something that would create better attitudes in the communfty and in the schools about a sex education program. Mrs. Buck, a doctor's wife, as spoken of in Dr. Calderone's article, is a person who became inspired with developing the program described. I am happy to know we are conducting in the community a series of workshops whose goal is to develop a nucleus of people to help develop programs of study that can be used by churches, YMCA's and various other community organizations. We are participating as a school district by affording our faculty members an opportunity to particlpate and receive in-service training credit toward advancement on our salary schedule. It is this nucleus of faculty members which we hope will form a committee which w1ll organize a more complete and positive program for the schools. When we have gone through this process I am sure any program we will have organized will be acceptable to the great majority of our citizens.

Dr. Calderone I believe has given a falrly complete description of how our community organized to develop these workshops. I belleve the organization she suggests will work with any community. I belleve any 
LONGVIEW PUBLIC SCHOOLS

Page 3 of Copy

communtty having gone through this process will be prepared to accept any kind of a famlily living education program including sex education which is developed. Without this background of work I believe any school will have to go through conslderable trial and error and much pain to develop an acceptable program. I think I should say as a result of our experience here that even participating in the program as suggested by $\mathrm{Dr}$. Calderone and developing a conmunity attitude as this program grows that you will still'find objection by some people. At least I expect to find some Individuals in our community who will raise objections to an improved and extended program on family life and sex education in the Longview Schools after many years of being exposed to it in a very moderate way.

I hope this is sufficient response to your request to help you on your way.

S/ Earl J. Reed, M.D., Superintendent 
APPENDIX F

HORTON'S PARADIGN FOR THE ANALYSIS OF CONFLICT' AND ORDER APPROACHES TO SOCIAL PROBLEMS

In order more sharply to compare order and conflict models in terms of their Implications for explanations of deviation and social problems, essential differences can be sumnartzed along a number of parallel dimensions. These dimensions are dichotomized into order and conflict categorles. The resulting paradigm can be used as a preliminary guide for the content analysis of contemporary as well as classical studies of social problens.

ORDER PERSPECTIVE

CONFLICT PERSPECTIVE

1. UNDERLYING SOCIAL PERSPECTIVE AND VALUE POSITIONS (IDEAL)

a. Image of man and society

Society as a natural boundarymaintaining system of action

Society as a contested struggle between groups with opposed aims and perspectives

Transcendent nature of society, Immanent conception of society ani an entity sui generis, greater than and different from the sun of its parts; lack of transcendence as lack of social control raeans anomy

Positive attitude toward the maintenance of soctal institutions

b. Human nature the social relationship; men are soclety; soclety is the extension of man, the indwelling of man; the transcendence of society is tantamount to the alienation of man from his own social nature

Positive attitude toward change

Homo duplex, man half egoistic (self-nature), half altruistic (socialized nature), ever in need of restraints for the collective good

Homo Zaborans existential man, the active creator of himself and soclety through practical and autonomous soctal action 
Tabula rasa, man equated with the soclallation process

or

Home damnatus, the division into morally supertor and morally inferior men

c. Values

The social good: balance, stability, authority, order, quantitative growth

Freedom as autonomy, change, action, qualitative growth ("moving equilibrium")

\section{MODES OF "SCIENTIFIC" ANALYSIS}

Natural science model: quest for general and universal laws and repeated patterns gleaned through empirical research

Multiple causality; theory characterized by high level of abstraction, but empirical. studies marked by low level of generalizetion (separation of theory from application)

Conditions of objectivity; accurate correspondence of concepts to facts; rigld separation of observer and facts observed passive, receptive theory of knowledge

Analysis begins with culture as major determinant of order and structure and proceeds to personality and social organization

Doninant concepts: ahistorical; high level of generality; hollstic; supra-individual concepts; ultimate referent for concepts - system needs considered universally (1:e., the functional prerequisites of any social system) or relativist1cally (i.e., present maintenance requirements of a particular social system)
Historical model: quest for understanding (Verstehen) through historical analysis of unique and changing events; possible use of ideal type of generalization based on historically specific patterns.

Unicausality; high or low level of theoretical generalization; union of theory and practice in soctal research and social action

Utility in terms of observer's interests; objectivity discussed in the context of subjectivity - activistic theory of knowledge

Analysis begins with organization of social activities or with growth and maintenance needs of man and proceeds to culture

Historical, dynamic; low level of generality and high level of historlcal specificity; ultimate referent for concepts - human needs considered universally (1.e., man's spectes nature) or relativistically (demands of particular contenders for power); referent often the future or an unrealized state of affairs 
3. ORDER AND CONFLICT THEORIES OF SOCIAL PROBLEMS AND DEVIATION

a. Standards for the definition of health and pathology

Health equated with existing values of a postulated society (or a dominent group in the society), Ideological definition

3. Evaluation of deviant behavior Pathological to the functioning of the soctal system

c. Explanation of deviation or a social problem

A problem of anomy in adequate control over competing groups in the social system; disequilibriun in the existing society

d. Implied ameliorative action Extension of soctal control (further and more effictent institutionalization of soclal system values); adjustment of individuals to system needs; working with-in the system; the administratıve sölution

Health equated with unrealized standards (the aspirations of subordinate but rising groups), utoplan definition

Posstbly progressive to the necessary transformation of existing relationships

A problem of self-alienation, being thwarted in the realization of individual and group goals; a problem of illegitimate social control and exploitation

Rupture of social control; radical transformation of existing patterns of interaction; revolutionary change of the social system

4. ORDER AND CONFLICT THEORIES AS SOCIALLY SITUATED VOCABULARIES

Dominant groups : the estabIIshment and administrators of the establishment

Contemporary representatives: Parsonian and Mertonian approach to social problems as a liberal vartent of order models; politically conservative approaches

Subordinate groups asplring for greater power

C. W. Mills, new left (SNCC, SDS, etc.) approaches the old left (socialistic and communistic) 
FOOTNOTES

${ }^{1}$ Curtis E. Avery and Margle R. Lee. "Famtly Life Education: Its PhIlosophy and Purpose". The Fanily Life Coordinator, Apr11, 1964, vol. 13 , no. 2 : pp. 43-49.

2Paul Brandwein. The Wortd of Living Things. New York: Harcourt, Brace and World, Inc., 1964.

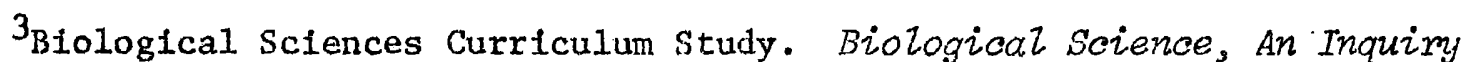
into Life. New York: Harcourt, Brace and World, Inc., 1963, pp. 473-475.

${ }^{4}$ Personal communication with health education supervisor.

5Multnomah County Medical Soclety. The BulZetin. vol. 22, no. 3, March, 1967.

6 Multnomah County Medical Society. The BulZetin. vol. 23, no. 3, March, 1958.

7"'Teachers' Exchange". Joumal of Marriage And the Family. May, 1967, vol. 29, no. 2: pp. 374-389.

${ }^{8}$ SIECUS Newsletter. Winter, 1968 , vol. 3, no. 4: p. 1.

${ }^{9}$ James W. Vander Zanden. American Minority Relations. New York: The Ronald Press Company, 1963, p. 429.

${ }^{10}$ Jerome S. Bruner. "Education As Social Invention". The Saturday Review, February 19, 1966, vol. 49, no. 8: p. 70.

${ }^{11}$ Ibid., p. 103 .

12 Joseph T. Klapper. The Effects of Mass Communication. New York: The Free Press, 1965, p. 8.

13 Ib1d. , p. 228-229.:

${ }^{14}$ Ibid., p. 32 .

${ }^{15}$ Alfred R. Lindesmith and Anselm L. Strauss. Social Psychology. rev. ed. New York: HoIt, Rinehart and Winston, 1956, p. 8.

${ }^{16}$ Sigmund Freud. Civilization and its Discontents. London: Hogarth Press, 1930, p. 85-86.

17sigmund Freud. Three Essays on the Theory of Sexuality. New York: Basic Books, 1962, preface xv. 


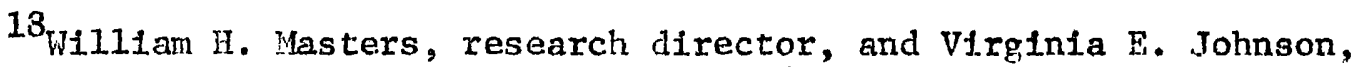
research assoclate. Human Sexual Response. Boston: Little, Brown and Co., 1966, preface vi.

${ }^{19}$ Anseln Strauss, ed., George Herbert Mead. On Social Psychology. The University of Chicago Press, 1964, p. 242.

20 IbId., p. 223.

${ }^{21}$ peter L. Berger. Invitation To Sociology: A Humanistic Perspective. Garden City: Anchor Books, Doubleday and Co., 1963, p. 148.

22 IbId., p. 142.

23 Talcott Parsons. Social Structure and Persorlality. London: The Free Press, 1964, p. 261.

${ }^{24}$ IbId., p. 261.

25 John Horton. "Order and Conflict Theories of Soctal Problems as Competing Ideologies". The American Joumal of Sociology. May 6, 1966, vo1. 71, no. 6: pp. 701-713.

${ }^{26}$ Parsons, op. cit., p. 274.

27 Ro11o May. "Extstential Bases of Psychotherapy", R. May, ed., Existential Psychology. New York: Random House, 1967, p. 77.

${ }^{28}$ Gordon Allport. "Cotument on Earlier Chapters". IbId., p. 98.

${ }^{29}$ Paul Goodman. Growing Up Absurd. New York: Randon House, 1960, p. 11 .

30 Hal and Jean Vermes. Helping Youth Avoid Four Great Dangers. New York: Association Press, 1965, pp. 108-111.

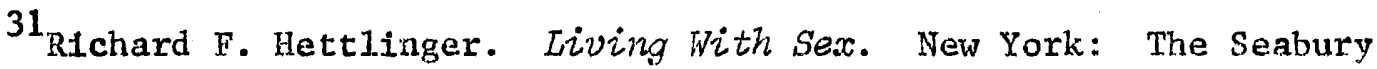
Press, 1966, pp. 67-68.

${ }^{32}$ James A. Pike. Teen-Agers and Sex. Englewood Cliffs, N. J.: Prentice Ha11, Inc., 1965, p. 140.

${ }^{33}$ Ibid. , p. 31.

${ }^{34}$ Personal communication with Dr. Lester Kirkendal1, May, 1967.

35. Abraham H. Maslow. Religions, Values, and Peak-Experiences.

Columbus: Ohfo State Universtty Press, 1964, pp. 114-116.

${ }^{36}$ Alan Watts. Nature, Man and Woman. New York: Pantheon Press, 1959. 
37 Lester A. KIrkenda11. Premarital Intercourse and Interpersonal Relationships. New York: Matr1x House, Ltd., 1966, p. 7.

${ }^{38}$ Ibid., pp. 229-251.

${ }^{39}$ Florian Znaniecki. Cultural Sciences, Their Origin and Development. Urbana: University of Illinois Press, 1963, p. 392.

40 Jerome S. Bruner. The Process of Education. New York: Random House, 1960, pp. 90-91.

${ }^{41}$ Carl R. Rogers. On Becoming a Person. Cambridge, Mass.: Riverside Press, 1961, p. 276.

42 Lee Rainwater. Family Design. Chicago: Aldine Publishing Co., 1965, pp. 278-280.

43 Bruner. "Education as Social Invention". p. 71. 